\title{
MEASUREMENT OF $\mathrm{pH}$. DEFINITION, STANDARDS, AND PROCEDURES
}

\section{(IUPAC Recommendations 2002)}

\author{
Working Party on $\mathrm{pH}$
}

R. P. BUCK (CHAIRMAN) ${ }^{1}$, S. RONDININI (SECRETARY) ${ }^{2, \ddagger}$, A. K. COVINGTON (EDITOR) ${ }^{3}$, F. G. K. BAUCKE ${ }^{4}$, C. M. A. BRETT ${ }^{5}$, M. F. CAMÕES ${ }^{6}$, M. J. T. MILTON ${ }^{7}$, T. MUSSINI ${ }^{8}$, R. NAUMANN ${ }^{9}$, K. W. PRATT ${ }^{10}$, P. SPITZER ${ }^{11}$, AND G. S. WILSON ${ }^{12}$

${ }^{1} 101$ Creekview Circle, Carrboro, NC 27510, USA; ${ }^{2}$ Dipartimento di Chimica Fisica ed Elettrochimica, Università di Milano, Via Golgi 19, I-20133 Milano, Italy; ${ }^{3}$ Department of Chemistry, The University, Bedson Building, Newcastle Upon Tyne, NE1 7RU, UK; ${ }^{4}$ Schott Glasswerke, P.O. Box 2480, D-55014 Mainz, Germany, ${ }^{5}$ Departamento de Química, Universidade de Coimbra, P-3004-535

Coimbra, Portugal; ${ }^{6}$ Departamento de Química e Bioquimica, University of Lisbon (SPQ/DQBFCUL), Faculdade de Ciencias, Edificio CI-5 Piso, P-1700 Lisboa, Portugal; ${ }^{7}$ National Physical Laboratory, Centre for Optical and Environmental Metrology, Queen's Road, Teddington, Middlesex TW11 OLW, UK; ${ }^{8}$ Dipartimento di Chimica Fisica ed Elettrochimica, Università di Milano, Via Golgi 19, I-20133 Milano, Italy; ${ }^{9}$ MPI for Polymer Research, Ackermannweg 10, D-55128 Mainz, Germany; ${ }^{10}$ Chemistry B324, Stop 8393, National Institute of Standards and Technology, 100 Bureau

Drive, ACSL, Room A349, Gaithersburg, MD 20899-8393, USA; ${ }^{11}$ Physikalisch-Technische Bundesanstalt (PTB), Postfach 33 45, D-38023 Braunschweig, Germany; ${ }^{12}$ Department of Chemistry, University of Kansas, Lawrence, KS 66045, USA need for formal IUPAC permission on condition that an acknowledgment, with full reference to the source, along with use of the copyright symbol $\odot$, the name IUPAC, and the year of publication, are prominently visible. Publication of a translation into another language is subject to the additional condition of prior approval from the relevant IUPAC National Adhering Organization. 


\title{
Measurement of $\mathrm{pH}$. Definition, standards, and procedures
}

\section{(IUPAC Recommendations 2002)}

\begin{abstract}
The definition of a "primary method of measurement" [1] has permitted a full consideration of the definition of primary standards for $\mathrm{pH}$, determined by a primary method (cell without transference, Harned cell), of the definition of secondary standards by secondary methods, and of the question whether $\mathrm{pH}$, as a conventional quantity, can be incorporated within the internationally accepted system of measurement, the International System of Units (SI, Système International d'Unités). This approach has enabled resolution of the previous compromise IUPAC 1985 Recommendations [2]. Furthermore, incorporation of the uncertainties for the primary method, and for all subsequent measurements, permits the uncertainties for all procedures to be linked to the primary standards by an unbroken chain of comparisons. Thus, a rational choice can be made by the analyst of the appropriate procedure to achieve the target uncertainty of sample $\mathrm{pH}$. Accordingly, this document explains IUPAC recommended definitions, procedures, and terminology relating to $\mathrm{pH}$ measurements in dilute aqueous solutions in the temperature range $5-50{ }^{\circ} \mathrm{C}$. Details are given of the primary and secondary methods for measuring $\mathrm{pH}$ and the rationale for the assignment of $\mathrm{pH}$ values with appropriate uncertainties to selected primary and secondary substances.
\end{abstract}

\author{
CONTENTS \\ 1. INTRODUCTION AND SCOPE \\ 2. ACTIVITY AND THE DEFINITION OF $\mathrm{pH}$ \\ 3. TRACEABILITY AND PRIMARY METHODS OF MEASUREMENT \\ 4. HARNED CELL AS A PRIMARY METHOD FOR ABSOLUTE MEASUREMENT OF $\mathrm{pH}$ \\ 5. SOURCES OF UNCERTAINTY IN THE USE OF THE HARNED CELL \\ 6. PRIMARY BUFFER SOLUTIONS AND THEIR REQUIRED PROPERTIES \\ 7. CONSISTENCY OF PRIMARY BUFFER SOLUTIONS \\ 8. SECONDARY STANDARDS AND SECONDARY METHODS OF MEASUREMENT \\ 9. CONSISTENCY OF SECONDARY BUFFER SOLUTIONS ESTABLISHED WITH RESPECT \\ TO PRIMARY STANDARDS \\ 10. TARGET UNCERTAINTIES FOR MEASUREMENT OF SECONDARY BUFFER \\ SOLUTIONS \\ 11. CALIBRATION OF $\mathrm{pH}$ METER-ELECTRODE ASSEMBLIES AND TARGET \\ UNCERTAINTIES FOR UNKNOWNS \\ 12. GLOSSARY \\ 13. ANNEX: MEASUREMENT UNCERTAINTY \\ 14. SUMMARY OF RECOMMENDATIONS \\ 15. REFERENCES
}




\section{ABBREVIATIONS USED}

$\begin{array}{ll}\text { BIPM } & \text { Bureau International des Poids et Mesures, France } \\ \text { CRMs } & \text { certified reference materials } \\ \text { EUROMET } & \text { European Collaboration in Metrology (Measurement Standards) } \\ \text { NBS } & \text { National Bureau of Standards, USA, now NIST } \\ \text { NIST } & \text { National Institute of Science and Technology, USA } \\ \text { NMIs } & \text { national metrological institutes } \\ \text { PS } & \text { primary standard } \\ \text { LJP } & \text { liquid junction potential } \\ \text { RLJP } & \text { residual liquid junction potential } \\ \text { SS } & \text { secondary standard }\end{array}$

\section{INTRODUCTION AND SCOPE}

\section{$1.1 \mathrm{pH}$, a single ion quantity}

The concept of $\mathrm{pH}$ is unique among the commonly encountered physicochemical quantities listed in the IUPAC Green Book [3] in that, in terms of its definition [4],

$$
\mathrm{pH}=-\lg a_{\mathrm{H}}
$$

it involves a single ion quantity, the activity of the hydrogen ion, which is immeasurable by any thermodynamically valid method and requires a convention for its evaluation.

\subsection{Cells without transference, Harned cells}

As will be shown in Section 4, primary $\mathrm{pH}$ standard values can be determined from electrochemical data from the cell without transference using the hydrogen gas electrode, known as the Harned cell. These primary standards have good reproducibility and low uncertainty. Cells involving glass electrodes and liquid junctions have considerably higher uncertainties, as will be discussed later (Sections 5.1, 10.1). Using evaluated uncertainties, it is possible to rank reference materials as primary or secondary in terms of the methods used for assigning $\mathrm{pH}$ values to them. This ranking of primary (PS) or secondary (SS) standards is consistent with the metrological requirement that measurements are traceable with stated uncertainties to national, or international, standards by an unbroken chain of comparisons each with its own stated uncertainty. The accepted definition of traceability is given in Section 12.4. If the uncertainty of such measurements is calculated to include the hydrogen ion activity convention (Section 4.6), then the result can also be traceable to the internationally accepted SI system of units.

\subsection{Primary pH standards}

In Section 4 of this document, the procedure used to assign primary standard [pH(PS)] values to primary standards is described. The only method that meets the stringent criteria of a primary method of measurement for measuring $\mathrm{pH}$ is based on the Harned cell (Cell I). This method, extensively developed by R. G. Bates [5] and collaborators at NBS (later NIST), is now adopted in national metrological institutes (NMIs) worldwide, and the procedure is approved in this document with slight modifications (Section 3.2) to comply with the requirements of a primary method. 


\subsection{Secondary standards derived from measurements on the Harned cell (Cell I)}

Values assigned by Harned cell measurements to substances that do not entirely fulfill the criteria for primary standard status are secondary standards (SS), with $\mathrm{pH}(\mathrm{SS})$ values, and are discussed in Section 8.1.

\subsection{Secondary standards derived from primary standards by measuring differences in $\mathrm{pH}$}

Methods that can be used to obtain the difference in $\mathrm{pH}$ between buffer solutions are discussed in Sections 8.2-8.5 of these Recommendations. These methods involve cells that are practically more convenient than the Harned cell, but have greater uncertainties associated with the results. They enable the $\mathrm{pH}$ of other buffers to be compared with primary standard buffers that have been measured with a Harned cell. It is recommended that these are secondary methods, and buffers measured in this way are secondary standards (SS), with $\mathrm{pH}(\mathrm{SS})$ values.

\subsection{Traceability}

This hierarchical approach to primary and secondary measurements facilitates the availability of traceable buffers for laboratory calibrations. Recommended procedures for carrying out these calibrations to achieve specified uncertainties are given in Section 11.

\subsection{Scope}

The recommendations in this Report relate to analytical laboratory determinations of $\mathrm{pH}$ of dilute aqueous solutions $\left(\leq 0.1 \mathrm{~mol} \mathrm{~kg}^{-1}\right)$. Systems including partially aqueous mixed solvents, biological measurements, heavy water solvent, natural waters, and high-temperature measurements are excluded from this Report.

\subsection{Uncertainty estimates}

The Annex (Section 13) includes typical uncertainty estimates for the use of the cells and measurements described.

\section{ACTIVITY AND THE DEFINITION OF pH}

\subsection{Hydrogen ion activity}

pH was originally defined by Sørensen in 1909 [6] in terms of the concentration of hydrogen ions (in modern nomenclature) as $\mathrm{pH}=-\lg \left(c_{\mathrm{H}} / c^{\circ}\right)$ where $c_{\mathrm{H}}$ is the hydrogen ion concentration in mol $\mathrm{dm}^{-3}$, and $c^{\circ}=1 \mathrm{~mol} \mathrm{dm}^{-3}$ is the standard amount concentration. Subsequently [4], it has been accepted that it is more satisfactory to define $\mathrm{pH}$ in terms of the relative activity of hydrogen ions in solution

$$
\mathrm{pH}=-\lg a_{\mathrm{H}}=-\lg \left(m_{\mathrm{H}} \gamma_{\mathrm{H}} / m^{\circ}\right)
$$

where $a_{\mathrm{H}}$ is the relative (molality basis) activity and $\gamma_{\mathrm{H}}$ is the molal activity coefficient of the hydrogen ion $\mathrm{H}^{+}$at the molality $m_{\mathrm{H}}$, and $m^{\circ}$ is the standard molality. The quantity $\mathrm{pH}$ is intended to be a measure of the activity of hydrogen ions in solution. However, since it is defined in terms of a quantity that cannot be measured by a thermodynamically valid method, eq. 1 can be only a notional definition of $\mathrm{pH}$. 


\section{TRACEABILITY AND PRIMARY METHODS OF MEASUREMENT}

\subsection{Relation to SI}

Since $\mathrm{pH}$, a single ion quantity, is not determinable in terms of a fundamental (or base) unit of any measurement system, there was some difficulty previously in providing a proper basis for the traceability of $\mathrm{pH}$ measurements. A satisfactory approach is now available in that $\mathrm{pH}$ determinations can be incorporated into the SI if they can be traced to measurements made using a method that fulfills the definition of a "primary method of measurement" [1].

\subsection{Primary method of measurement}

The accepted definition of a primary method of measurement is given in Section 12.1. The essential feature of such a method is that it must operate according to a well-defined measurement equation in which all of the variables can be determined experimentally in terms of SI units. Any limitation in the determination of the experimental variables, or in the theory, must be included within the estimated uncertainty of the method if traceability to the SI is to be established. If a convention is used without an estimate of its uncertainty, true traceability to the SI would not be established. In the following section, it is shown that the Harned cell fulfills the definition of a primary method for the measurement of the acidity function, $\mathrm{p}\left(a_{\mathrm{H}} \gamma_{\mathrm{Cl}}\right)$, and subsequently of the $\mathrm{pH}$ of buffer solutions.

\section{HARNED CELL AS A PRIMARY METHOD FOR THE ABSOLUTE MEASUREMENT OF pH}

\subsection{Harned cell}

The cell without transference defined by

$$
\mathrm{Pt}\left|\mathrm{H}_{2}\right| \text { buffer } \mathrm{S}, \mathrm{Cl}^{-}|\mathrm{AgCl}| \mathrm{Ag}
$$

Cell I

known as the Harned cell [7], and containing standard buffer, S, and chloride ions, in the form of potassium or sodium chloride, which are added in order to use the silver-silver chloride electrode. The application of the Nernst equation to the spontaneous cell reaction:

$$
1 / 2 \mathrm{H}_{2}+\mathrm{AgCl} \rightarrow \mathrm{Ag}(\mathrm{s})+\mathrm{H}^{+}+\mathrm{Cl}^{-}
$$

yields the potential difference $E_{\mathrm{I}}$ of the cell [corrected to $1 \mathrm{~atm}(101.325 \mathrm{kPa})$, the partial pressure of hydrogen gas used in electrochemistry in preference to $100 \mathrm{kPa}$ ] as

$$
E_{\mathrm{I}}=E^{\circ}-[(R T / F) \ln 10] \lg \left[\left(m_{\mathrm{H}} \gamma_{\mathrm{H}} / m^{\circ}\right)\left(m_{\mathrm{Cl}} \gamma_{\mathrm{Cl}} / m^{\circ}\right)\right]
$$

which can be rearranged, since $a_{\mathrm{H}}=m_{\mathrm{H}} \gamma_{\mathrm{H}} / m^{\circ}$, to give the acidity function

$$
\mathrm{p}\left(a_{\mathrm{H}} \gamma_{\mathrm{Cl}}\right)=-\lg \left(a_{\mathrm{H}} \gamma_{\mathrm{Cl}}\right)=\left(E_{\mathrm{I}}-E^{\circ}\right) /[(R T / F) \ln 10]+\lg \left(m_{\mathrm{Cl}} / m^{\circ}\right)
$$

where $E^{\circ}$ is the standard potential difference of the cell, and hence of the silver-silver chloride electrode, and $\gamma_{\mathrm{Cl}}$ is the activity coefficient of the chloride ion.

Note 1: The sign of the standard electrode potential of an electrochemical reaction is that displayed on a high-impedance voltmeter when the lead attached to standard hydrogen electrode is connected to the minus pole of the voltmeter. graphs.

The steps in the use of the cell are summarized in Fig. 1 and described in the following para- 


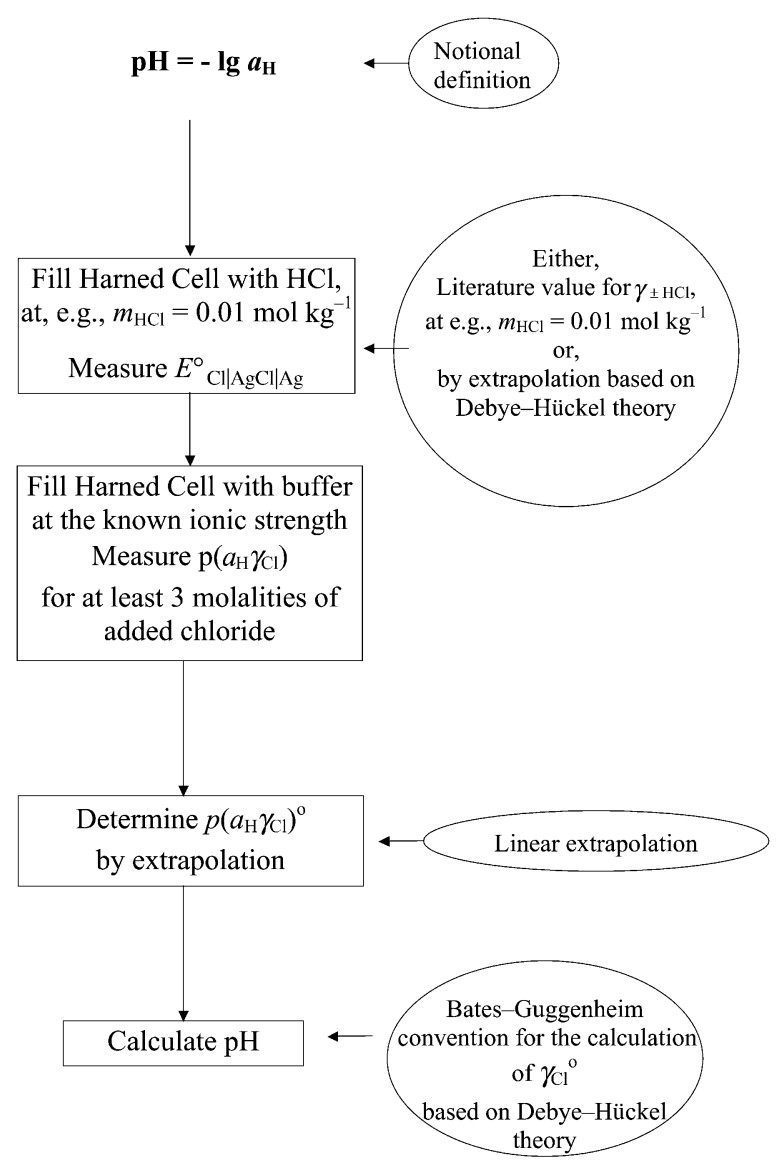

Fig. 1 Operation of the Harned cell as a primary method for the measurement of absolute pH.

The standard potential difference of the silver-silver chloride electrode, $E^{\circ}$, is determined from a Harned cell in which only $\mathrm{HCl}$ is present at a fixed molality (e.g., $m=0.01 \mathrm{~mol} \mathrm{~kg}^{-1}$ ). The application of the Nernst equation to the $\mathrm{HCl}$ cell

$\mathrm{Pt}\left|\mathrm{H}_{2}\right| \mathrm{HCl}(m)|\mathrm{AgCl}| \mathrm{Ag}$

Cell Ia

gives

$$
E_{\mathrm{Ia}}=E^{\circ}-[(2 R T / F) \ln 10] \lg \left[\left(m_{\mathrm{HCl}} / m^{\circ}\right)\left(\gamma_{ \pm \mathrm{HCl}}\right)\right]
$$

where $E_{\mathrm{Ia}}$ has been corrected to 1 atmosphere partial pressure of hydrogen gas $(101.325 \mathrm{kPa})$ and $\gamma_{ \pm \mathrm{HCl}}$ is the mean ionic activity coefficient of $\mathrm{HCl}$.

\subsection{Activity coefficient of $\mathrm{HCl}$}

The values of the activity coefficient $\left(\gamma_{ \pm \mathrm{HCl}}\right)$ at molality $0.01 \mathrm{~mol} \mathrm{~kg}^{-1}$ and various temperatures are given by Bates and Robinson [8]. The standard potential difference depends in some not entirely understood way on the method of preparation of the electrodes, but individual determinations of the activity coefficient of $\mathrm{HCl}$ at $0.01 \mathrm{~mol} \mathrm{~kg}^{-1}$ are more uniform than values of $E^{\circ}$. Hence, the practical determination of the potential difference of the cell with $\mathrm{HCl}$ at $0.01 \mathrm{~mol} \mathrm{~kg}^{-1}$ is recommended at $298.15 \mathrm{~K}$ at which the mean ionic activity coefficient is 0.904 . Dickson [9] concluded that it is not necessary to 
repeat the measurement of $E^{\circ}$ at other temperatures, but that it is satisfactory to correct published smoothed values by the observed difference in $E^{\circ}$ at $298.15 \mathrm{~K}$.

\subsection{Acidity function}

In NMIs, measurements of Cells I and Ia are often done simultaneously in a thermostat bath. Subtracting eq. 3 from eq. 2 gives

$$
\Delta E=E_{\mathrm{I}}-E_{\mathrm{Ia}}=-[(R T / F) \ln 10]\left\{\lg \left[\left(m_{\mathrm{H}} \gamma_{\mathrm{H}} / m^{\circ}\right)\left(m_{\mathrm{Cl}} \gamma_{\mathrm{Cl}} / m^{\circ}\right)\right]-\lg \left[\left(m_{\mathrm{HCl}} / m^{\circ}\right)^{2} \gamma_{ \pm \mathrm{HCl}}^{2}\right]\right\},
$$

which is independent of the standard potential difference. Therefore, the subsequently calculated $\mathrm{pH}$ does not depend on the standard potential difference and hence does not depend on the assumption that the standard potential of the hydrogen electrode, $E^{\circ}\left(\mathrm{H}^{+} \mid \mathrm{H}_{2}\right)=0$ at all temperatures. Therefore, the Harned cell can give an exact comparison between hydrogen ion activities at two different temperatures (in contrast to statements found elsewhere, see, for example, ref. [5]).

The quantity $\mathrm{p}\left(a_{\mathrm{H}} \gamma_{\mathrm{Cl}}\right)=-\lg \left(a_{\mathrm{H}} \gamma_{\mathrm{Cl}}\right)$, on the left-hand side of eq. $2^{\prime}$, is called the acidity function [5]. To obtain the quantity $\mathrm{pH}$ (according to eq. 1 ), from the acidity function, it is necessary to evaluate $\lg \gamma_{\mathrm{Cl}}$ by independent means. This is done in two steps: (i) the value of $\lg \left(a_{\mathrm{H}} \gamma_{\mathrm{Cl}}\right)$ at zero chloride molality, $\lg \left(a_{\mathrm{H}} \gamma_{\mathrm{Cl}}\right)^{\circ}$, is evaluated and (ii) a value for the activity of the chloride ion $\gamma^{\circ} \mathrm{Cl}$, at zero chloride molality (sometimes referred to as the limiting or "trace" activity coefficient [9]) is calculated using the Bates-Guggenheim convention [10]. These two steps are described in the following paragraphs.

\subsection{Extrapolation of acidity function to zero chloride molality}

The value of $\lg \left(a_{\mathrm{H}} \gamma_{\mathrm{Cl}}\right)^{\circ}$ corresponding to zero chloride molality is determined by linear extrapolation of measurements using Harned cells with at least three added molalities of sodium or potassium chloride $\left(I<0.1 \mathrm{~mol} \mathrm{~kg}^{-1}\right.$, see Sections 4.5 and 12.6)

$$
-\lg \left(a_{\mathrm{H}} \gamma_{\mathrm{Cl}}\right)=-\lg \left(a_{\mathrm{H}} \gamma_{\mathrm{Cl}}\right)^{\circ}+S m_{\mathrm{Cl}},
$$

where $S$ is an empirical, temperature-dependent constant. The extrapolation is linear, which is expected from Brønsted's observations [11] that specific ion interactions between oppositely charged ions are dominant in mixed strong electrolyte systems at constant molality or ionic strength. However, these acidity function measurements are made on mixtures of weak and strong electrolytes at constant buffer molality, but not constant total molality. It can be shown [12] that provided the change in ionic strength on addition of chloride is less than $20 \%$, the extrapolation will be linear without detectable curvature. If the latter, less-convenient method of preparation of constant total molality solutions is used, Bates [5] has reported that, for equimolal phosphate buffer, the two methods extrapolate to the same intercept. In an alternative procedure, often useful for partially aqueous mixed solvents where the above extrapolation appears to be curved, multiple application of the Bates-Guggenheim convention to each solution composition gives identical results within the estimated uncertainty of the two intercepts.

\subsection{Bates-Guggenheim convention}

The activity coefficient of chloride (like the activity coefficient of the hydrogen ion) is an immeasurable quantity. However, in solutions of low ionic strength $\left(I<0.1 \mathrm{~mol} \mathrm{~kg}^{-1}\right)$, it is possible to calculate the activity coefficient of chloride ion using the Debye-Hückel theory. This is done by adopting the Bates-Guggenheim convention, which assumes the trace activity coefficient of the chloride ion $\gamma^{\circ} \mathrm{Cl}$ is given by the expression [10].

$$
\lg \gamma_{\mathrm{Cl}}^{\circ}=-A I^{1 / 2} /\left(1+B a I^{1 / 2}\right)
$$


where $A$ is the Debye-Hückel temperature-dependent constant (limiting slope), $a$ is the mean distance of closest approach of the ions (ion size parameter), $B a$ is set equal to $\left.1.5(\mathrm{~mol} \mathrm{~kg})^{-1}\right)^{-1 / 2}$ at all temperatures in the range $5-50{ }^{\circ} \mathrm{C}$, and $I$ is the ionic strength of the buffer (which, for its evaluation requires knowledge of appropriate acid dissociation constants). Values of $A$ as a function of temperature can be found in Table A- 6 and of $B$, which is effectively unaffected by revision of dielectric constant data, in Bates [5]. When the numerical value of $B a=1.5$ (i.e., without units) is introduced into eq. 6 it should be written as

$$
\lg \gamma_{\mathrm{Cl}}^{\circ}=-A I^{1 / 2 /[}\left[1+1.5\left(I / m^{\circ}\right)^{1 / 2}\right]
$$

The various stages in the assignment of primary standard $\mathrm{pH}$ values are combined in eq. 7 , which is derived from eqs. $2^{\prime}, 5,6^{\prime}$,

$$
\mathrm{pH}(\mathrm{PS})=\lim m_{\mathrm{Cl} \rightarrow 0}\left\{\left(E_{\mathrm{I}}-E^{\circ}\right) /[(R T / F) \ln 10]+\lg \left(m_{\mathrm{Cl}} / m^{\circ}\right)\right\}-A I^{1 / 2} /\left[1+1.5\left(I / m^{\circ}\right)^{1 / 2}\right],
$$

and the steps are summarized schematically in Fig. 1.

\section{SOURCES OF UNCERTAINTY IN THE USE OF THE HARNED CELL}

\subsection{Potential primary method and uncertainty evaluation}

The presentation of the procedure in Section 4 highlights the fact that assumptions based on electrolyte theories [7] are used at three points in the method:

i. The Debye-Hückel theory is the basis of the extrapolation procedure to calculate the value for the standard potential of the silver-silver chloride electrode, even though it is a published value of $\gamma_{ \pm \mathrm{HCl}}$ at, e.g., $m=0.01 \mathrm{~mol} \mathrm{~kg}^{-1}$, that is recommended (Section 4.2 ) to facilitate $E^{\circ}$ determination.

ii. Specific ion interaction theory is the basis for using a linear extrapolation to zero chloride (but the change in ionic strength produced by addition of chloride should be restricted to no more than $20 \%$ ).

iii. The Debye-Hückel theory is the basis for the Bates-Guggenheim convention used for the calculation of the trace activity coefficient, $\gamma^{\circ} \mathrm{Cl}$.

In the first two cases, the inadequacies of electrolyte theories are sources of uncertainty that limit the extent to which the measured $\mathrm{pH}$ is a true representation of $\lg a_{\mathrm{H}}$. In the third case, the use of eq. 6 or 7 is a convention, since the value for $B a$ is not directly determinable experimentally. Previous recommendations have not included the uncertainty in $B a$ explicitly within the calculation of the uncertainty of the measurement.

Since eq. 2 is derived from the Nernst equation applied to the thermodynamically well-behaved platinum-hydrogen and silver-silver chloride electrodes, it is recommended that, when used to measure $-\lg \left(a_{\mathrm{H}} \gamma_{\mathrm{Cl}}\right)$ in aqueous solutions, the Harned cell potentially meets the agreed definition of a primary method for the measurement. The word "potentially" has been included to emphasize that the method can only achieve primary status if it is operated with the highest metrological qualities (see Sections 6.1-6.2). Additionally, if the Bates-Guggenheim convention is used for the calculation of $\lg \gamma_{\mathrm{Cl}}^{\circ}$, the Harned cell potentially meets the agreed definition of a primary method for the measurement of $\mathrm{pH}$, subject to this convention if a realistic estimate of its uncertainty is included. The uncertainty budget for the primary method of measurement by the Harned cell (Cell I) is given in the Annex, Section 13.

Note 2: The experimental uncertainty for a typical primary $\mathrm{pH}(\mathrm{PS})$ measurement is of the order of 0.004 (see Table 4). 


\subsection{Evaluation of uncertainty of the Bates-Guggenheim convention}

In order for a measurement of $\mathrm{pH}$ made with a Harned cell to be traceable to the SI system, an estimate of the uncertainty of each step must be included in the result. Hence, it is recommended that an estimate of the uncertainty of 0.01 (95\% confidence interval) in $\mathrm{pH}$ associated with the Bates-Guggenheim convention is used. The extent to which the Bates-Guggenheim convention represents the "true" (but immeasurable) activity coefficient of the chloride ion can be calculated by varying the coefficient $B a$ between 1.0 and $2.0\left(\mathrm{~mol} \mathrm{~kg}^{-1}\right)^{1 / 2}$. This corresponds to varying the ion-size parameter between 0.3 and $0.6 \mathrm{~nm}$, yielding a range of \pm 0.012 (at $I=0.1 \mathrm{~mol} \mathrm{~kg}^{-1}$ ) and \pm 0.007 (at $I=0.05 \mathrm{~mol} \mathrm{~kg}^{-1}$ ) for $\gamma^{\circ} \mathrm{Cl}$ calculated using equation [7]. Hence, an uncertainty of 0.01 should cover the full extent of variation. This must be included in the uncertainty of $\mathrm{pH}$ values that are to be regarded as traceable to the SI. $\mathrm{pH}$ values stated without this contribution to their uncertainty cannot be considered to be traceable to the SI.

\subsection{Hydrogen ion concentration}

It is rarely required to calculate hydrogen ion concentration from measured $\mathrm{pH}$. Should such a calculation be required, the only consistent, logical way of doing it is to assume $\gamma_{\mathrm{H}}=\gamma_{\mathrm{Cl}}$ and set the latter to the appropriate Bates-Guggenheim conventional value. The uncertainties are then those derived from the Bates-Guggenheim convention.

\subsection{Possible future approaches}

Any model of electrolyte solutions that takes into account both electrostatic and specific interactions for individual solutions would be an improvement over use of the Bates-Guggenheim convention. It is hardly reasonable that a fixed value of the ion-size parameter should be appropriate for a diversity of selected buffer solutions. It is hoped that the Pitzer model of electrolytes [13], which uses a virial equation approach, will provide such an improvement, but data in the literature are insufficiently extensive to make these calculations at the present time. From limited work at $25{ }^{\circ} \mathrm{C}$ done on phosphate and carbonate buffers, it seems that changes to Bates-Guggenheim recommended values will be small [14]. It is possible that some anomalies attributed to liquid junction potentials (LJPs) may be resolved.

\section{PRIMARY BUFFER SOLUTIONS AND THEIR REQUIRED PROPERTIES}

\subsection{Requisites for highest metrological quality}

In the previous sections, it has been shown that the Harned cell provides a primary method for the determination of $\mathrm{pH}$. In order for a particular buffer solution to be considered a primary buffer solution, it must be of the "highest metrological" quality [15] in accordance with the definition of a primary standard. It is recommended that it have the following attributes [5: p. 95;16,17]:

- $\quad$ High buffer value in the range 0.016-0.07 $\left(\mathrm{mol} \mathrm{OH}^{-}\right) / \mathrm{pH}$

- Small dilution value at half concentration (change in $\mathrm{pH}$ with change in buffer concentration) in the range $0.01-0.20$

- $\quad$ Small dependence of $\mathrm{pH}$ on temperature less than $\pm 0.01 \mathrm{~K}^{-1}$

- $\quad$ Low residual LJP $<0.01$ in $\mathrm{pH}$ (see Section 7)

- $\quad$ Ionic strength $\leq 0.1 \mathrm{~mol} \mathrm{~kg}^{-1}$ to permit applicability of the Bates-Guggenheim convention

- $\quad$ NMI certificate for specific batch

- $\quad$ Reproducible purity of preparation (lot-to-lot differences of $|\Delta \mathrm{pH}(\mathrm{PS})|<0.003$ )

- $\quad$ Long-term stability of stored solid material

Values for the above and other important parameters for the selected primary buffer materials (see Section 6.2) are given in Table 1.

(C) 2002 IUPAC, Pure and Applied Chemistry 74, 2169-2200 


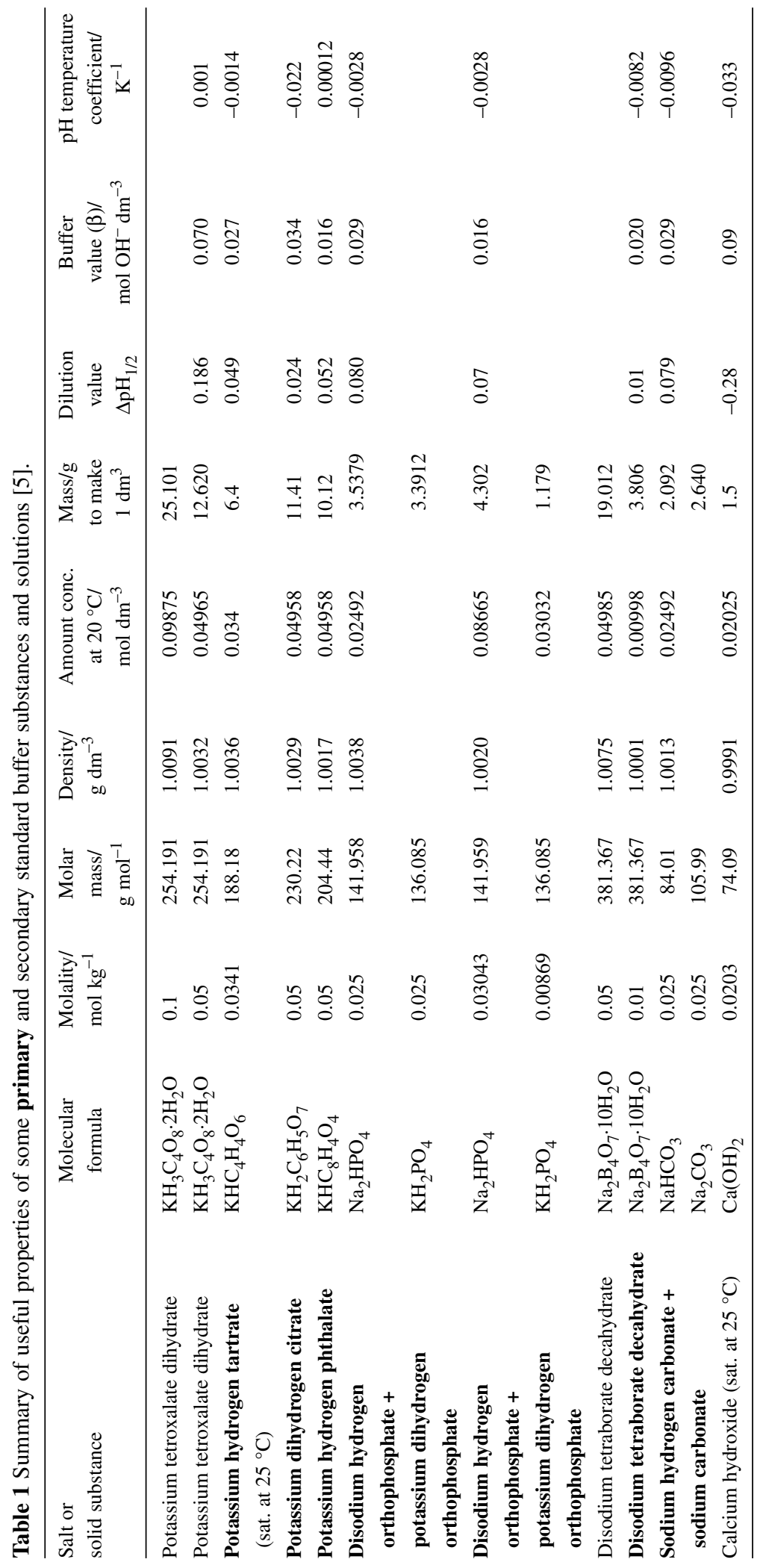

(C) 2002 IUPAC, Pure and Applied Chemistry 74, 2169-2200 
Note 3: The long-term stability of the solid compounds ( $>5$ years) is a requirement not met by borax [16]. There are also doubts about the extent of polyborate formation in $0.05 \mathrm{~mol} \mathrm{~kg}^{-1}$ borax solutions, and hence this solution is not accorded primary status.

\subsection{Primary standard buffers}

Since there can be significant variations in the purity of samples of a buffer of the same nominal chemical composition, it is essential that the primary buffer material used has been certified with values that have been measured with Cell I. The Harned cell has been used by many NMIs for accurate measurements of $\mathrm{pH}$ of buffer solutions. Comparisons of such measurements have been carried out under EUROMET collaboration [18], which have demonstrated the high comparability of measurements ( 0.005 in $\mathrm{pH})$ in different laboratories of samples from the same batch of buffer material. Typical values of the $\mathrm{pH}(\mathrm{PS})$ of the seven solutions from the six accepted primary standard reference buffers, which meet the conditions stated in Section 6.1, are listed in Table 2. These listed $\mathrm{pH}(\mathrm{PS})$ values have been derived from certificates issued by NBS/NIST over the past 35 years. Batch-to-batch variations in purity can result in changes in the $\mathrm{pH}$ value of samples of at most 0.003 . The typical values in Table 2 should not be used in place of the certified value (from a Harned cell measurement) for a specific batch of buffer material.

Table 2 Typical values of $\mathrm{pH}(\mathrm{PS})$ for primary standards at $0-50{ }^{\circ} \mathrm{C}$ (see Section 6.2).

\begin{tabular}{|c|c|c|c|c|c|c|c|c|c|c|c|}
\hline \multirow[b]{2}{*}{ Primary standards (PS) } & \multicolumn{11}{|c|}{ Temp. $/{ }^{\circ} \mathrm{C}$} \\
\hline & 0 & 5 & 10 & 15 & 20 & 25 & 30 & 35 & 37 & 40 & 50 \\
\hline $\begin{array}{l}\text { Sat. potassium hydrogen } \\
\text { tartrate }\left(\text { at } 25^{\circ} \mathrm{C}\right)\end{array}$ & & & & & & 3.557 & 3.552 & 3.549 & 3.548 & 3.547 & 3.549 \\
\hline $\begin{array}{l}0.05 \mathrm{~mol} \mathrm{~kg}^{-1} \text { potassium } \\
\text { dihydrogen citrate }\end{array}$ & 3.863 & 3.840 & 3.820 & 3.802 & 3.788 & 3.776 & 3.766 & 3.759 & 3.756 & 3.754 & 3.749 \\
\hline $\begin{array}{l}0.05 \mathrm{~mol} \mathrm{~kg}^{-1} \text { potassium } \\
\text { hydrogen phthalate }\end{array}$ & 4.000 & 3.998 & 3.997 & 3.998 & 4.000 & 4.005 & 4.011 & 4.018 & 4.022 & 4.027 & 4.050 \\
\hline $\begin{array}{l}0.025 \mathrm{~mol} \mathrm{~kg}^{-1} \text { disodium } \\
\text { hydrogen phosphate }+ \\
0.025 \mathrm{~mol} \mathrm{~kg}^{-1} \text { potassium } \\
\text { dihydrogen phosphate }\end{array}$ & 6.984 & 6.951 & 6.923 & 6.900 & 6.881 & 6.865 & 6.853 & 6.844 & 6.841 & 6.838 & 6.833 \\
\hline $\begin{array}{l}0.03043 \mathrm{~mol} \mathrm{~kg}^{-1} \text { disodium } \\
\text { hydrogen phosphate }+ \\
0.008695 \mathrm{~mol} \mathrm{~kg}^{-1} \text { potassium } \\
\text { dihydrogen phosphate }\end{array}$ & 7.534 & 7.500 & 7.472 & 7.448 & 7.429 & 7.413 & 7.400 & 7.389 & 7.386 & 7.380 & 7.367 \\
\hline $\begin{array}{l}0.01 \mathrm{~mol} \mathrm{~kg}^{-1} \text { disodium } \\
\text { tetraborate }\end{array}$ & 9.464 & 9.395 & 9.332 & 9.276 & 9.225 & 9.180 & 9.139 & 9.102 & 9.088 & 9.068 & 9.011 \\
\hline $\begin{array}{l}0.025 \mathrm{~mol} \mathrm{~kg}^{-1} \text { sodium } \\
\text { hydrogen carbonate }+ \\
0.025 \mathrm{~mol} \mathrm{~kg}^{-1} \text { sodium } \\
\text { carbonate }\end{array}$ & 10.317 & 10.245 & 10.179 & 10.118 & 10.062 & 10.012 & 9.966 & 9.926 & 9.910 & 9.889 & 9.828 \\
\hline
\end{tabular}

The required attributes listed in Section 6.1 effectively limit the range of primary buffers available to between $\mathrm{pH} 3$ and 10 (at $25{ }^{\circ} \mathrm{C}$ ). Calcium hydroxide and potassium tetroxalate have been excluded because the contribution of hydroxide or hydrogen ions to the ionic strength is significant. Also excluded are the nitrogen bases of the type $\mathrm{BH}^{+}$[such as tris(hydroxymethyl)aminomethane and 
piperazine phosphate] and the zwitterionic buffers (e.g., HEPES and MOPS [19]). These do not comply because either the Bates-Guggenheim convention is not applicable, or the LJPs are high. This means the choice of primary standards is restricted to buffers derived from oxy-carbon, -phosphorus, -boron, and mono, di-, and tri-protic carboxylic acids. In the future, other buffer systems may fulfill the requirements listed in Section 6.1.

\section{CONSISTENCY OF PRIMARY BUFFER SOLUTIONS}

\subsection{Consistency and the liquid junction potential}

Primary methods of measurement are made with cells without transference as described in Sections 1-6 (Cell I). Less-complex, secondary methods use cells with transference, which contain liquid junctions. A single LJP is immeasurable, but differences in LJP can be estimated. LJPs vary with the composition of the solutions forming the junction and the geometry of the junction.

Equation 7 for Cell I applied successively to two primary standard buffers, $\mathrm{PS}_{1}, \mathrm{PS}_{2}$, gives

$$
\begin{aligned}
& \Delta \mathrm{pH}_{\mathrm{I}}=\mathrm{pH}_{\mathrm{I}}\left(\mathrm{PS}_{2}\right)-\mathrm{pH}_{\mathrm{I}}\left(\mathrm{PS}_{1}\right)=\lim m_{\mathrm{Cl} \rightarrow 0}\left\{E_{\mathrm{I}}\left(\mathrm{PS}_{2}\right) / k-E_{\mathrm{I}}\left(\mathrm{PS}_{1}\right) / k\right\}-A\left\{I_{(2)}{ }^{1 / 2} /[1+1.5\right. \\
& \left.\left(I_{(2)} / m^{\circ}\right)^{1 / 2}\right]-I_{(1)} /\left[/\left[1+1.5\left(I_{(1)} / m^{\circ}\right)^{1 / 2}\right]\right\}
\end{aligned}
$$

where $k=(R T / F) \ln 10$ and the last term is the ratio of trace chloride activity coefficients $\lg \left[\gamma^{\circ} \mathrm{Cl}(2)^{l} \gamma_{\mathrm{Cl}(1)}^{\circ}\right]$, conventionally evaluated via B-G eq. $6^{\prime}$.

Note 4: Since the convention may unevenly affect the $\gamma^{\circ}{ }_{\mathrm{Cl}(2)}$ and $\gamma^{\circ} \mathrm{Cl(1)}$ estimations, $\Delta \mathrm{pH}_{\mathrm{I}}$ differs from the true value by the unknown contribution: $\lg \left[\gamma_{\mathrm{Cl}(2)}^{\circ} \gamma^{\circ} \mathrm{Cl(1)}\right]-A\left\{I_{(1)^{1 / 2 /[}}{ }^{1 / 1}+\right.$ $\left.\left.1.5\left(I_{(1)} / m^{\circ}\right)^{1 / 2}\right]-I_{(2)} 1 / 2 /\left[1+1.5\left(I_{(2)} / m^{\circ}\right)^{1 / 2}\right]\right\}$.

A second method of comparison is by measurement of Cell II in which there is a salt bridge with two free-diffusion liquid junctions

$$
\mathrm{Pt}\left|\mathrm{H}_{2}\right| \mathrm{PS}_{2}: \mathrm{KCl}\left(\geq 3.5 \mathrm{~mol} \mathrm{dm}^{-3}\right) \mathrm{PS}_{1}\left|\mathrm{H}_{2}\right| \mathrm{Pt}
$$

Cell II

for which the spontaneous cell reaction is a dilution,

$$
\mathrm{H}^{+}\left(\mathrm{PS}_{1}\right) \rightarrow \mathrm{H}^{+}\left(\mathrm{PS}_{2}\right)
$$

which gives the $\mathrm{pH}$ difference from Cell II as

$$
\Delta \mathrm{pH}_{\mathrm{II}}=\mathrm{pH}_{\mathrm{II}}\left(\mathrm{PS}_{2}\right)-\mathrm{pH}_{\mathrm{II}}\left(\mathrm{PS}_{1}\right)=E_{\mathrm{II}} / k-\left[\left(E_{\mathrm{j} 2}-E_{\mathrm{j} 1}\right) / k\right]
$$

where the subscript II is used to indicate that the $\mathrm{pH}$ difference between the same two buffer solutions is now obtained from Cell II. $\Delta \mathrm{pH}_{\mathrm{II}}$ differs from $\Delta \mathrm{pH}_{\mathrm{I}}$ (and both differ from the true value $\Delta \mathrm{pH}_{\mathrm{I}}$ ) since it depends on unknown quantity, the residual LJP, RLJP $=\left(E_{\mathrm{j} 2}-E_{\mathrm{j} 1}\right)$, whose exact value could be determined if the true $\Delta \mathrm{pH}$ were known.

Note 5: The subject of liquid junction effects in ion-selective electrode potentiometry has been comprehensively reviewed [20]. Harper [21] and Bagg [22] have made computer calculations of LJPs for simple three-ion junctions (such as $\mathrm{HCl}+\mathrm{KCl}$ ), the only ones for which mobility and activity coefficient data are available. Breer, Ratkje, and Olsen [23] have thoroughly examined the possible errors arising from the commonly made approximations in calculating LJPs for three-ion junctions. They concluded that the assumption of linear concentration profiles has less-severe consequences $(\sim 0.1-1.0 \mathrm{mV})$ than the other two assumptions of the Henderson treatment, namely constant mobilities and neglect of activity coefficients, which can lead to errors in the order of $10 \mathrm{mV}$. Breer et al. concluded that their calculations supported an earlier statement [24] that in ion-selective electrode potentiometry, the theoretical Nernst slope, even for dilute sample solutions, could never be attained because of liquid junction effects. 
Note 6: According to IUPAC recommendations on nomenclature and symbols [3], a single vertical bar $(\mid)$ is used to represent a phase boundary, a dashed vertical bar $\left(\begin{array}{l}1 \\ 1\end{array}\right)$ represents a liquid-liquid junction between two electrolyte solutions (across which a potential difference will occur), and a double dashed vertical bar ( II) represents a similar liquid junction, in which the LJP is assumed to be effectively zero ( $\sim 1 \%$ of cell potential difference). Hence, terms such as that in square brackets on the right-hand side of eq. 9 are usually ignored, and the liquid junction is represented by II. However, in the Annex, the symbol $!$ is used because the error associated with the liquid junction is included in the analysis. For ease of comparison, numbers of related equations in the main text and in the Annex are indicated.

Note 7: The polarity of Cell II will be negative on the left, i.e., $-\mid+$, when $\mathrm{pH}\left(\mathrm{PS}_{2}\right)>\mathrm{pH}\left(\mathrm{PS}_{1}\right)$. The LJP $E_{\mathrm{j}}$ of a single liquid junction is defined as the difference in (Galvani) potential contributions to the total cell potential difference arising at the interface from the buffer solution less that from the $\mathrm{KCl}$ solution. For instance, in Cell II, $E_{\mathrm{j} 1}=E\left(\mathrm{~S}_{1}\right)-E(\mathrm{KCl})$ and $E_{\mathrm{j} 2}=E\left(\mathrm{~S}_{2}\right)-E(\mathrm{KCl})$. It is negative when the buffer solution of interest is acidic and positive when it is alkaline, provided that $E_{\mathrm{j}}$ is principally caused by the hydrogen, or hydroxide, ion content of the solution of interest (and only to a smaller degree by its alkali ions or anions). The residual liquid junction potential (RLJP), the difference $E_{\mathrm{j}}$ (right) $-E_{\mathrm{j}}($ left), depends on the relative magnitudes of the individual $E_{\mathrm{j}}$ values and has the opposite polarity to the potential difference $E$ of the cell. Hence, in Cell II the RLJP, $E_{\mathrm{j} 1}\left(\mathrm{PS}_{1}\right)-E_{\mathrm{j} 2}\left(\mathrm{PS}_{2}\right)$, has a polarity $+\mid-$ when $\mathrm{pH}\left(\mathrm{S}_{2}\right)>\mathrm{pH}\left(\mathrm{S}_{1}\right)$.

Notwithstanding the foregoing, comparison of $\mathrm{pH}_{\mathrm{II}}$ values from the Cell II with two liquid junctions (eq. 9) with the assigned $\mathrm{pH}_{\mathrm{I}}(\mathrm{PS})$ values for the same two primary buffers measured with Cell I (eq. 8) makes an estimation of RLJPs possible [5]:

$$
\left[\mathrm{pH}_{\mathrm{I}}\left(\mathrm{PS}_{2}\right)-\mathrm{pH}_{\mathrm{II}}\left(\mathrm{PS}_{2}\right)\right]-\left[\mathrm{pH}_{\mathrm{I}}\left(\mathrm{PS}_{1}\right)-\mathrm{pH}_{\mathrm{II}}\left(\mathrm{PS}_{1}\right)\right]=\left(E_{\mathrm{j} 2}-E_{\mathrm{j} 1}\right) / k=\mathrm{RLJP}
$$

With the value of RLJP set equal to zero for equimolal phosphate buffer (taken as $\mathrm{PS}_{1}$ ) then $\left[\mathrm{pH}_{\mathrm{I}}\left(\mathrm{PS}_{2}\right)-\mathrm{pH}_{\mathrm{II}}\left(\mathrm{PS}_{2}\right)\right]$ is plotted against $\mathrm{pH}(\mathrm{PS})$. Results for free-diffusion liquid junctions formed in a capillary tube with cylindrical symmetry at $25^{\circ} \mathrm{C}$ are shown in Fig. 2 [25, and refs. cited therein].

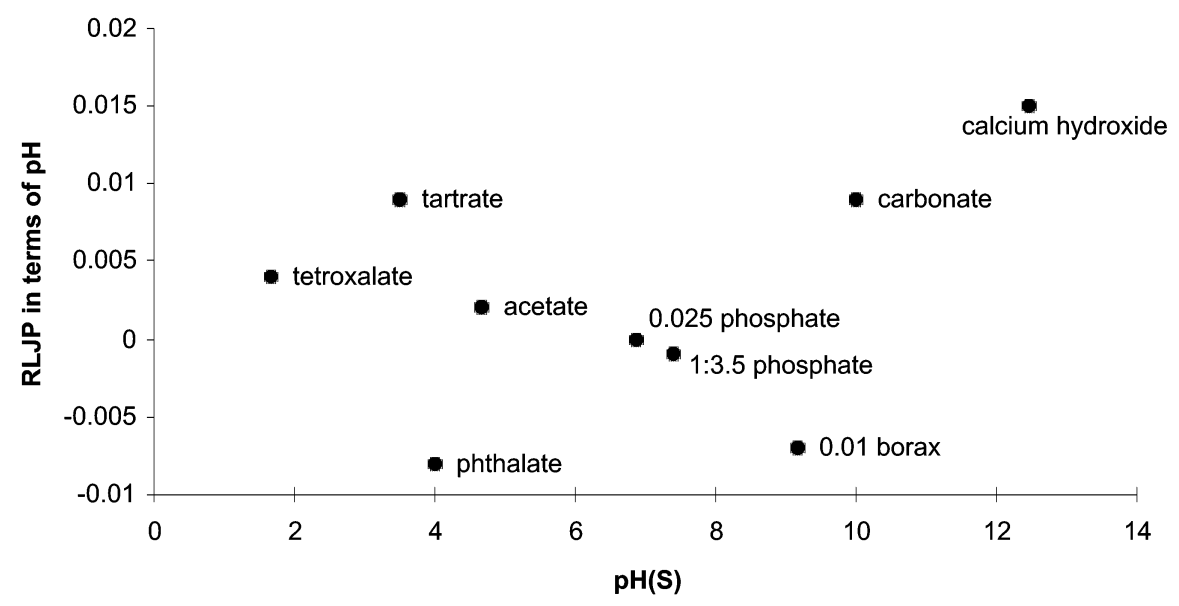

Fig. 2 Some values of residual LJPs in terms of $\mathrm{pH}$ with reference to the value for $0.025 \mathrm{~mol} \mathrm{~kg}^{-1} \mathrm{Na}_{2} \mathrm{HPO}_{4}+$ $0.025 \mathrm{~mol} \mathrm{~kg}^{-1} \mathrm{KH}_{2} \mathrm{PO}_{4}(0.025$ phosphate buffer $)$ taken as zero [25]. 
Note 8: For $0.05 \mathrm{~mol} \mathrm{~kg}^{-1}$ tetroxalate, the published values [26] for Cell II with free-diffusion junctions are wrong $[27,28]$.

Values such as those shown in Fig. 2 give an indication of the extent of possible systematic uncertainties for primary standard buffers arising from three sources:

i. Experimental uncertainties, including any variations in the chemical purity of primary buffer materials (or variations in the preparation of the solutions) if measurements of Cells I and II were not made in the same laboratory at the same occasion.

ii. Variation in RLJPs between primary buffers.

iii. Inconsistencies resulting from the application of the Bates-Guggenheim convention to chemically different buffer solutions of ionic strengths less than $0.1 \mathrm{~mol} \mathrm{~kg}^{-1}$.

It may be concluded from examination of the results in Fig. 2, that a consistency no better than 0.01 can be ascribed to the primary $\mathrm{pH}$ standard solutions of Table 2 in the $\mathrm{pH}$ range 3-10. This value will be greater for less reproducibly formed liquid junctions than the free-diffusion type with cylindrical symmetry.

Note 9: Considering the conventional nature of eq. 10, and that the irreproducibility of formation of geometry-dependent devices exceeds possible bias between carefully formed junctions of known geometry, the RLJP contribution, which is included in the difference between measured potential differences of cells with transference, is treated as a statistical, and not a systematic error.

Note 10: Values of RLJP depend on the Bates-Guggenheim convention through the last term in eq. 8 and would be different if another convention were chosen. This interdependence of the single ion activity coefficient and the LJP may be emphasized by noting that it would be possible arbitrarily to reduce RLJP values to zero for each buffer by adjusting the ion-size parameter in eq. 6 .

\subsection{Computational approach to consistency}

The consistency between conventionally assigned $\mathrm{pH}$ values can also be assessed by a computational approach. The $\mathrm{pH}$ values of standard buffer solutions have been calculated from literature values of acid dissociation constants by an iterative process. The arbitrary extension of the Bates-Guggenheim convention for chloride ion, to all ions, leads to the calculation of ionic activity coefficients of all ionic species, ionic strength, buffer capacity, and calculated $\mathrm{pH}$ values. The consistency of these values with primary $\mathrm{pH}$ values obtained using Cell I was 0.01 or lower between 10 and $40{ }^{\circ} \mathrm{C}[29,30]$.

\section{SECONDARY STANDARDS AND SECONDARY METHODS OF MEASUREMENT}

\subsection{Secondary standards derived from Harned cell measurements}

Substances that do not fulfill all the criteria for primary standards but to which $\mathrm{pH}$ values can be assigned using Cell I are considered to be secondary standards. Reasons for their exclusion as primary standards include, inter alia:

i. Difficulties in achieving consistent, suitable chemical quality (e.g., acetic acid is a liquid).

ii. High LJP, or inappropriateness of the Bates-Guggenheim convention (e.g., other charge-type buffers).

Therefore, they do not comply with the stringent criterion for a primary measurement of being of the highest metrological quality. Nevertheless, their $\mathrm{pH}(\mathrm{SS})$ values can be determined. Their consis- 
tency with the primary standards should be checked with the method described in Section 7. The primary and secondary standard materials should be accompanied by certificates from NMIs in order for them to be described as certified reference materials (CRMs). Some illustrative $\mathrm{pH}(\mathrm{SS})$ values for secondary standard materials $[5,17,25,31,32]$ are given in Table 3 .

Table 3 Values of pH(SS) of some secondary standards from Harned Cell I measurements.

\begin{tabular}{|c|c|c|c|c|c|c|c|c|c|c|}
\hline \multirow[b]{2}{*}{ Secondary standards } & \multicolumn{10}{|c|}{ Temp. $/{ }^{\circ} \mathrm{C}$} \\
\hline & 0 & 5 & 10 & 15 & 20 & 25 & 30 & 37 & 40 & 50 \\
\hline $\begin{array}{l}0.05 \mathrm{~mol} \mathrm{~kg}^{-1} \text { potassium } \\
\text { tetroxalate } \\
{[5,17]}\end{array}$ & & 1.67 & 1.67 & 1.67 & 1.68 & 1.68 & 1.68 & 1.69 & 1.69 & 1.71 \\
\hline $\begin{array}{l}0.05 \mathrm{~mol} \mathrm{~kg}^{-1} \text { sodium hydrogen } \\
\text { diglycolate }^{\mathrm{b}}[31]\end{array}$ & & 3.47 & 3.47 & 3.48 & 3.48 & 3.49 & 3.50 & 3.52 & 3.53 & 3.56 \\
\hline $\begin{array}{l}0.1 \mathrm{~mol} \mathrm{dm}^{-3} \text { acetic acid }+ \\
0.1 \mathrm{~mol} \mathrm{dm}^{-3} \text { sodium acetate [25] }\end{array}$ & 4.68 & 4.67 & 4.67 & 4.66 & 4.66 & 4.65 & 4.65 & 4.66 & 4.66 & 4.68 \\
\hline $\begin{array}{l}0.1 \mathrm{~mol} \mathrm{dm}^{-3} \text { acetic acid }+ \\
0.1 \mathrm{~mol} \mathrm{dm}^{-3} \text { sodium acetate [25] }\end{array}$ & 4.74 & 4.73 & 4.73 & 4.72 & 4.72 & 4.72 & 4.72 & 4.73 & 4.73 & 4.75 \\
\hline $\begin{array}{l}0.02 \mathrm{~mol} \mathrm{~kg}^{-1} \text { piperazine } \\
\text { phosphate }^{\mathrm{c}}[32]\end{array}$ & 6.58 & 6.51 & 6.45 & 6.39 & 6.34 & 6.29 & 6.24 & 6.16 & 6.14 & 6.06 \\
\hline $\begin{array}{l}0.05 \mathrm{~mol} \mathrm{~kg}^{-1} \text { tris hydrochloride }+ \\
0.01667 \mathrm{~mol} \mathrm{~kg}^{-1} \text { tris }^{\mathrm{c}}\end{array}$ & 8.47 & 8.30 & 8.14 & 7.99 & 7.84 & 7.70 & 7.56 & 7.38 & 7.31 & 7.07 \\
\hline $\begin{array}{l}0.05 \mathrm{~mol} \mathrm{~kg}^{-1} \text { disodium } \\
\text { tetraborate }\end{array}$ & 9.51 & 9.43 & 9.36 & 9.30 & 9.25 & 9.19 & 9.15 & 9.09 & 9.07 & 9.01 \\
\hline $\begin{array}{l}\text { Saturated (at } 25^{\circ} \mathrm{C} \text { ) calcium } \\
\text { hydroxide [5] }\end{array}$ & 13.42 & 13.21 & 13.00 & 12.81 & 12.63 & 12.45 & 12.29 & 12.07 & 11.98 & 11.71 \\
\hline
\end{tabular}

${ }^{\mathrm{a}}$ potassium trihydrogen dioxalate $\left(\mathrm{KH}_{3} \mathrm{C}_{4} \mathrm{O}_{8}\right)$

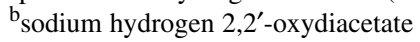

c2-amino-2-(hydroxymethyl)-1,3 propanediol or tris(hydroxymethyl)aminomethane

\subsection{Secondary standards derived from primary standards}

In most applications, the use of a high-accuracy primary standard for $\mathrm{pH}$ measurements is not justified, if a traceable secondary standard of sufficient accuracy is available. Several designs of cells are available for comparing the $\mathrm{pH}$ values of two buffer solutions. However, there is no primary method for measuring the difference in $\mathrm{pH}$ between two buffer solutions for reasons given in Section 8.6. Such measurements could involve either using a cell successively with two buffers, or a single measurement with a cell containing two buffer solutions separated by one or two liquid junctions.

\subsection{Secondary standards derived from primary standards of the same nominal composition using cells without salt bridge}

The most direct way of comparing $\mathrm{pH}(\mathrm{PS})$ and $\mathrm{pH}(\mathrm{SS})$ is by means of the single-junction Cell III [33].

$$
\mathrm{Pt}\left|\mathrm{H}_{2}\right| \text { buffer } \mathrm{S}_{2}: \text { i buffer } \mathrm{S}_{1}\left|\mathrm{H}_{2}\right| \mathrm{Pt}
$$

The cell reaction for the spontaneous dilution reaction is the same as for Cell II, and the $\mathrm{pH}$ difference is given, see Note 6, by

$$
\mathrm{pH}\left(\mathrm{S}_{2}\right)-\mathrm{pH}\left(\mathrm{S}_{1}\right)=E_{\mathrm{III}} / k
$$

The buffer solutions containing identical $\mathrm{Pt} \mid \mathrm{H}_{2}$ electrodes with an identical hydrogen pressure are in direct contact via a vertical sintered glass disk of a suitable porosity $(40 \mu \mathrm{m})$. The LJP formed between the two standards of nominally the same composition will be particularly small and is esti- 
mated to be in the $\mu \mathrm{V}$ range. It will, therefore, be less than $10 \%$ of the potential difference measured if the $\mathrm{pH}(\mathrm{S})$ values of the standard solutions are in the range $3 \leq \mathrm{pH}(\mathrm{S}) \leq 11$ and the difference in their $\mathrm{pH}(\mathrm{S})$ values is not larger than 0.02 . Under these conditions, the LJP is not dominated by the hydrogen and hydroxyl ions but by the other ions (anions, alkali metal ions). The proper functioning of the cell can be checked by measuring the potential difference when both sides of the cell contain the same solution.

\subsection{Secondary standards derived from primary standards using cells with salt bridge}

The cell that includes a hydrogen electrode [corrected to 1 atm $(101.325 \mathrm{kPa})$ partial pressure of hydrogen] and a reference electrode, the filling solution of which is a saturated or high concentration of the almost equitransferent electrolyte, potassium chloride, hence minimizing the LJP, is, see Note 6:

$\mathrm{Ag}|\mathrm{AgCl}| \mathrm{KCl}\left(\geq 3.5 \mathrm{~mol} \mathrm{dm}^{-3}\right)$ " buffer $\mathrm{S}\left|\mathrm{H}_{2}\right| \mathrm{Pt}$

Cell IV

Note 11: Other electrolytes, e.g., rubidium or cesium chloride, are more equitransferent [34].

Note 12: Cell IV is written in the direction: reference | indicator

i. for conformity of treatment of all hydrogen ion-responsive electrodes and ion-selective electrodes with various choices of reference electrode, and partly,

ii. for the practical reason that $\mathrm{pH}$ meters usually have one low impedance socket for the reference electrode, assumed negative, and a high-impedance terminal with a different plug, usually for a glass electrode.

With this convention, whatever the form of hydrogen ion-responsive electrode used (e.g., glass or quinhydrone), or whatever the reference electrode, the potential of the hydrogen-ion responsive electrode always decreases (becomes more negative) with increasing pH (see Fig. 3).

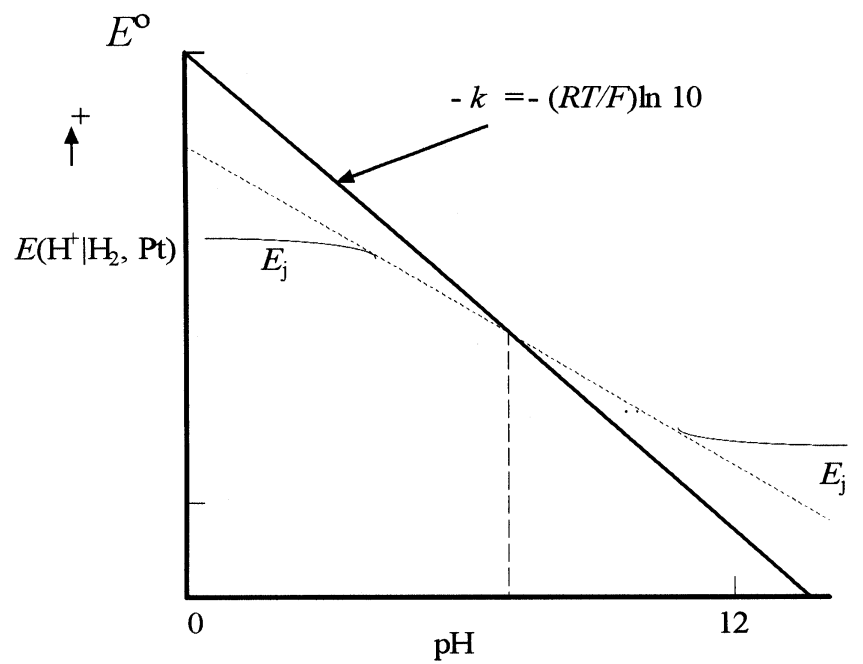

Fig. 3 Schematic plot of the variation of potential difference (-) for the cell ${ }^{-} \mathrm{Ag}|\mathrm{AgCl}| \mathrm{KCl} \mathrm{H}{ }^{+}$(buffer) $\left|\mathrm{H}_{2}\right| \mathrm{Pt}^{+}$ with $\mathrm{pH}$ and illustrating the choice of sign convention. The effect of LJP is indicated $(\longrightarrow$ ) with its variation of $\mathrm{pH}$ as given by the Henderson equation (see, e.g., ref. [5]). The approximate linearity (----) in the middle pH region should be noted. Both lines have been grossly exaggerated in their deviation from the Nernst line since otherwise they would be indistinguishable from each other and the Nernst line. For the calomel electrode $\mathrm{Hg}\left|\mathrm{Hg}_{2} \mathrm{Cl}_{2}\right| \mathrm{KCl}$ and the thallium amalgam $\mid$ thallium(I) chloride electrode $\mathrm{Hg}|\mathrm{Tl}(\mathrm{Hg})| \mathrm{TlCl} \mid \mathrm{KCl}$, or any other constant potential reference electrode, the diagram is the same. 
This convention was used in the 1985 document [2] and is also consistent with the treatment of ion-selective electrodes [35]. In effect, it focuses attention on the indicator electrode, for which the potential is then given by the Nernst equation for the single-electrode potential, written as a reduction process, in accord with the Stockholm convention [36]:

$$
\text { For Ox }+n \mathrm{e}^{-} \rightarrow \mathrm{Red}, \quad E=E^{\circ}-(k / n) \lg \left(a_{\text {red }} / a_{\text {ox }}\right)
$$

(where $a$ is activity), or, for the hydrogen gas electrode at 1 atm partial pressure of hydrogen gas:

$$
\mathrm{H}^{+}+\mathrm{e}^{-} \rightarrow 1 / 2 \mathrm{H}_{2} \quad E=E^{\circ}+k \lg a_{\mathrm{H}^{+}}=E^{\circ}-k \mathrm{pH}
$$

The equation for Cell IV is, therefore:

$$
\mathrm{pH}(\mathrm{S})=-\left[E_{\mathrm{IV}}(\mathrm{S})-E_{\mathrm{IV}}{ }^{\prime}\right] / k
$$

in which $E_{\mathrm{IV}}{ }^{\prime}$ is the standard potential, which includes the term $\lg a_{\mathrm{Cl}} / m^{\circ}$, and $E_{\mathrm{j}}$ is the LJP.

Note 13: Mercury-mercury(I) chloride (calomel) and thallium amalgam-thallium (I) chloride reference electrodes are alternative choices to the silver-silver chloride electrode in Cell IV. solutions

The consecutive use of two such cells containing buffers $\mathrm{S}_{1}$ and $\mathrm{S}_{2}$ gives the $\mathrm{pH}$ difference of the

$$
\mathrm{pH}\left(\mathrm{S}_{2}\right)-\mathrm{pH}\left(\mathrm{S}_{1}\right)=-\left[E_{\mathrm{IV}}\left(\mathrm{S}_{2}\right)-E_{\mathrm{IV}}\left(\mathrm{S}_{1}\right)\right] / k
$$

Note 14: Experimentally, a three-limb electrode vessel allowing simultaneous measurement of two Cell IIs may be used [25] with the advantage that the stability with time of the electrodes and of the liquid junctions can be checked. The measurement of cells of type II, which has a salt bridge with two liquid junctions, has been discussed in Section 7 .

Cells II and IV may also be used to measure the value of secondary buffer standards that are not compatible with the silver-silver chloride electrode used in Cell I. Since the LJPs in Cells II and IV are minimized by the use of an equitransferent salt, these cells are suitable for use with secondary buffers that have a different concentration and/or an ionic strength greater than the limit $\left(I \leq 0.1 \mathrm{~mol} \mathrm{~kg}^{-1}\right)$ imposed by the Bates-Guggenheim convention. They may, however, also be used for comparing solutions of the same nominal composition.

\subsection{Secondary standards from glass electrode cells}

Measurements cannot be made with a hydrogen electrode in Cell IV, for example, if the buffer is reduced by hydrogen gas at the platinum (or palladium-coated platinum) electrode. Cell $\mathrm{V}$ involving a glass electrode and silver-silver chloride reference electrode may be used instead in consecutive measurements, with two buffers $S_{1}, S_{2}$ (see Section 11 for details).

\subsection{Secondary methods}

The equations given for Cells II to V show that these cannot be considered primary (ratio) methods for measuring $\mathrm{pH}$ difference [1], (see also Section 12.1) because the cell reactions involve transference, or the irreversible inter-diffusion of ions, and hence an LJP contribution to the measured potential difference. The value of this potential difference depends on the ionic constituents, their concentrations and the geometry of the liquid junction between the solutions. Hence, the measurement equations contain terms that, although small, are not quantifiable, and the methods are secondary not primary. 


\section{CONSISTENCY OF SECONDARY STANDARD BUFFER SOLUTIONS ESTABLISHED WITH RESPECT TO PRIMARY STANDARDS}

\subsection{Summary of procedures for establishing secondary standards}

The following procedures may be distinguished for establishing secondary standards (SS) with respect to primary standards:

i. $\quad$ For SS of the same nominal composition as PS, use Cells III or II.

ii. For SS of different composition, use Cells IV or II.

iii. For SS not compatible with platinum hydrogen electrode, use Cell V (see Section 11.1).

Although any of Cells II to V could be used for certification of secondary standards with stated uncertainty, employing different procedures would lead to inconsistencies. It would be difficult to define specific terminology to distinguish each of these procedures or to define any rigorous hierarchy for them. Hence, the methods should include estimates of the typical uncertainty for each. The choice between methods should be made according to the uncertainty required for the application (see Section 10 and Table 4).

\subsection{Secondary standard evaluation from primary standards of the same composition}

It is strongly recommended that the preferred method for assigning secondary standards should be a procedure (i) in which measurements are made with respect to the primary buffer of nominally the same chemical composition. All secondary standards should be accompanied by a certificate relating to that particular batch of reference material as significant batch-to-batch variations are likely to occur. Some secondary standards are disseminated in solution form. The uncertainty of the $\mathrm{pH}$ values of such solutions may be larger than those for material disseminated in solid form.

\subsection{Secondary standard evaluation when there is no primary standard of the same composition}

It may sometimes be necessary to set up a secondary standard when there is no primary standard of the same chemical composition available. It will, therefore, be necessary to use either Cells II, IV, or V, and a primary or secondary standard buffer of different chemical composition. Buffers measured in this way will have a different status from those measured with respect to primary standards because they are not directly traceable to a primary standard of the same chemical composition. This different status should be reflected in the, usually larger, uncertainty quoted for such a buffer. Since this situation will only occur for buffers when a primary standard is not available, no special nomenclature is recommended to distinguish the different routes to secondary standards. Secondary buffers of a composition different from those of primary standards can also be derived from measurements on Cell I, provided the buffer is compatible with Cell I. However, the uncertainty of such standards should reflect the limitations of the secondary standard (see Table 4).

\section{TARGET UNCERTAINTIES FOR THE MEASUREMENT OF SECONDARY BUFFER SOLUTIONS}

\subsection{Uncertainties of secondary standards derived from primary standards}

Cells II to IV (and occasionally Cell V) are used to measure secondary standards with respect to primary standards. In each case, the limitations associated with the measurement method will result in a greater uncertainty for the secondary standard than the primary standard from which it was derived. 
Target uncertainties are listed in Table 4. However, these uncertainties do not take into account the uncertainty contribution arising from the adoption of the Bates-Guggenheim convention to achieve traceability to SI units.

Table 4 Summary of recommended target uncertainties.

\begin{tabular}{|c|c|c|}
\hline & $\begin{array}{c}U(\mathrm{pH}) \\
\text { (For coverage } \\
\text { factor 2) }\end{array}$ & Comments \\
\hline \multicolumn{3}{|l|}{$\begin{array}{l}\text { PRIMARY STANDARDS } \\
\end{array}$} \\
\hline Uncertainty of PS measured (by an NMI) with Harned Cell I & 0.004 & \\
\hline Repeatability of PS measured (by an NMI) with Harned Cell I & 0.0015 & \\
\hline Reproducibility of measurements in comparisons with Harned Cell I & 0.003 & EUROMET comparisons \\
\hline Typical variations between batches of PS buffers & 0.003 & \\
\hline \multicolumn{3}{|l|}{ SECONDARY STANDARDS } \\
\hline Value of SS compared with same PS material with Cell III & 0.004 & $\begin{array}{l}\text { increase in uncertainty is } \\
\text { negligible relative to PS used }\end{array}$ \\
\hline Value of SS measured in Harned Cell I & 0.01 & e.g., biological buffers \\
\hline Value of SS labeled against different PS with Cell II or IV & 0.015 & \\
\hline Value of SS (not compatible with $\mathrm{Pt} \mid \mathrm{H}_{2}$ ) measured with Cell V & 0.02 & example based on phthalate \\
\hline \multicolumn{3}{|l|}{ ELECTRODE CALIBRATION } \\
\hline Multipoint (5-point) calibration & $0.01-0.03$ & \\
\hline Calibration (2-point) by bracketing & $0.02-0.03$ & \\
\hline Calibration (1-point), $\Delta \mathrm{pH}=3$ and assumed slope & 0.3 & \\
\hline
\end{tabular}

Note: None of the above include the uncertainty associated with the Bates-Guggenheim convention so the results cannot be considered to be traceable to SI (see Section 5.2).

\subsection{Uncertainty evaluation [37]}

Summaries of typical uncertainty calculations for Cells I-V are given in the Annex (Section 13).

\section{CALIBRATION OF pH METER-ELECTRODE ASSEMBLIES AND TARGET UNCERTAINTIES FOR UNKNOWNS}

\subsection{Glass electrode cells}

Practical $\mathrm{pH}$ measurements are carried out by means of Cell $\mathrm{V}$

reference electrode $\mid \mathrm{KCl}\left(\mathrm{c} \geq 3.5 \mathrm{~mol} \mathrm{dm}^{-3}\right)$ " solution $[\mathrm{pH}(\mathrm{S})$ or $\mathrm{pH}(\mathrm{X})]$ | glass electrode Cell $\mathrm{V}$ and $\mathrm{pH}(\mathrm{X})$ is obtained, see Note 6 , from eq. 14

$\mathrm{pH}(\mathrm{X})=\mathrm{pH}(\mathrm{S})-\left[E_{\mathrm{V}}(\mathrm{X})-E_{\mathrm{V}}(\mathrm{S})\right]$

This is a one-point calibration (see Section 11.3).

These cells often use glass electrodes in the form of single probes or combination electrodes (glass and reference electrodes fashioned into a single probe, a so-called "combination electrode").

The potential difference of Cell V is made up of contributions arising from the potentials of the glass and reference electrodes and the liquid junction (see Section 7.1).

Various random and systematic effects must be noted when using these cells for $\mathrm{pH}$ measurements: 
i. Glass electrodes may exhibit a slope of the $E$ vs. $\mathrm{pH}$ function smaller than the theoretical value $[k=(R T / F) \ln 10]$, often called a sub-Nernstian response or practical slope $k^{\prime}$, which is experimentally determinable. A theoretical explanation for the sub-Nernstian response of $\mathrm{pH}$ glass electrodes in terms of the dissociation of functional groups at the glass surface has been given [38].

ii. The response of the glass electrode may vary with time, history of use, and memory effects. It is recommended that the response time and the drift of the electrodes be taken into account [39].

iii. The potential of the glass electrode is strongly temperature-dependent, as to a lesser extent are the other two terms. Calibrations and measurements should, therefore, be carried out under temperature-controlled conditions.

iv. The LJP varies with the composition of the solutions forming the junction, e.g., with $\mathrm{pH}$ (see Fig. 2). Hence, it will change if one solution $[\mathrm{pH}(\mathrm{S})$ or $\mathrm{pH}(\mathrm{X})]$ in Cell $\mathrm{V}$ is replaced by another. It is also affected by the geometry of the liquid junction device. Hence, it may be different if a free-diffusion type junction, such as that used to measure the RLJP (see Section 7.1), is replaced by another type, such as a sleeve, ceramic diaphragm, fiber, or platinum junction [39,40].

v. Liquid junction devices, particularly some commercial designs, may suffer from memory and clogging effects.

vi. The LJP may be subject to hydrodynamic effects, e.g., stirring.

Since these effects introduce errors of unknown magnitude, the measurement of an unknown sample requires a suitable calibration procedure. Three procedures are in common use based on calibrations at one point (one-point calibration), two points (two-point calibration or bracketing) and a series of points (multipoint calibration).

\subsection{Target uncertainties for unknowns}

Uncertainties in $\mathrm{pH}(\mathrm{X})$ are obtained, as shown below, by several procedures involving different numbers of experiments. Numerical values of these uncertainties obtained from the different calibration procedures are, therefore, not directly comparable. It is, therefore, not possible at the present time to make a universal recommendation of the best procedure to adopt for all applications. Hence, the target uncertainty for the unknown is given, which the operator of a $\mathrm{pH}$ meter electrode assembly may reasonably seek to achieve. Values are given for each of the three techniques (see Table 4), but the uncertainties attainable experimentally are critically dependent on the factors listed in Section 11.1 above, on the quality of the electrodes, and on the experimental technique for changing solutions.

In order to obtain the overall uncertainty of the measurement, uncertainties of the respective $\mathrm{pH}(\mathrm{PS})$ or $\mathrm{pH}(\mathrm{SS})$ values must be taken into account (see Table 4). Target uncertainties given below, and in Table 4, refer to calibrations performed by the use of standard buffer solutions with an uncertainty $U[\mathrm{pH}(\mathrm{PS})]$ or $U[\mathrm{pH}(\mathrm{SS})] \mathrm{d} 0.01$. The overall uncertainty becomes higher if standards with higher uncertainties are used.

\subsection{One-point calibration}

A single-point calibration is insufficient to determine both slope and one-point parameters. The theoretical value for the slope can be assumed, but the practical slope may be up to $5 \%$ lower. Alternatively, a value for the practical slope can be assumed from the manufacturer's prior calibration. The one-point calibration, therefore, yields only an estimate of $\mathrm{pH}(\mathrm{X})$. Since both parameters may change with age of the electrodes, this is not a reliable procedure. Based on a measurement for which $\Delta \mathrm{pH}=\mathrm{pH}(\mathrm{X})-$ $\mathrm{pH}(\mathrm{S}) \mid=5$, the expanded uncertainty would be $U=0.5 \mathrm{in} \mathrm{pH}(\mathrm{X})$ for $k^{\prime}=0.95 k$, but assumed theoretical, or $U=0.3$ in $\mathrm{pH}(\mathrm{X})$ for $\Delta \mathrm{pH}=|\mathrm{pH}(\mathrm{X})-\mathrm{pH}(\mathrm{S})|=3$ (see Table 4). This approach could be satisfactory for certain applications. The uncertainty will decrease with decreasing difference $\mathrm{pH}(\mathrm{X})-$ $\mathrm{pH}(\mathrm{S})$ and be smaller if $k^{\prime}$ is known from prior calibration. 


\subsection{Two-point calibration target uncertainty, $U[\mathrm{pH}(\mathrm{X})]=0.02-0.03$ at $25{ }^{\circ} \mathrm{C}$ \}}

In the majority of practical applications, glass electrodes cells (Cell V) are calibrated by two-point calibration, or bracketing, procedure using two standard buffer solutions, with $\mathrm{pH}$ values $\mathrm{pH}\left(\mathrm{S}_{1}\right)$ and $\mathrm{pH}\left(\mathrm{S}_{2}\right)$, bracketing the unknown $\mathrm{pH}(\mathrm{X})$. Bracketing is often taken to mean that the $\mathrm{pH}\left(\mathrm{S}_{1}\right)$ and $\mathrm{pH}\left(\mathrm{S}_{2}\right)$ buffers selected should be those that are immediately above and below $\mathrm{pH}(\mathrm{X})$. This may not be appropriate in all situations and choice of a wider range may be better.

If the respective potential differences measured are $E_{\mathrm{V}}\left(\mathrm{S}_{1}\right), E_{\mathrm{V}}\left(\mathrm{S}_{2}\right)$, and $E_{\mathrm{V}}(\mathrm{X})$, the $\mathrm{pH}$ value of the unknown, $\mathrm{pH}(\mathrm{X})$, is obtained from eq. 15

$$
\mathrm{pH}(\mathrm{X})=\mathrm{pH}\left(\mathrm{S}_{1}\right)-\left[E_{\mathrm{V}}(\mathrm{X})-E_{\mathrm{V}}\left(\mathrm{S}_{1}\right)\right] / k^{\prime}
$$

where the practical slope factor $\left(k^{\prime}\right)$ is given by

$$
k^{\prime}=\left[E_{\mathrm{V}}\left(\mathrm{S}_{1}\right)-E_{\mathrm{V}}\left(\mathrm{S}_{2}\right)\right] /\left[\mathrm{pH}\left(\mathrm{S}_{2}\right)-\mathrm{pH}\left(\mathrm{S}_{1}\right)\right]
$$

An example is given in the Annex, Section 13.

\subsection{Multipoint calibration \{target uncertainty: $U[\mathrm{pH}(\mathrm{X})]=0.01-0.03$ at $25^{\circ} \mathrm{C}$ \}}

Multipoint calibration is carried out using up to five standard buffers $[39,40]$. The use of more than five points does not yield any significant improvement in the statistical information obtainable.

The calibration function of Cell $\mathrm{V}$ is given by eq. 17

$$
E_{\mathrm{V}}(\mathrm{S})=E_{\mathrm{V}}{ }^{\circ}-k^{\prime} \mathrm{pH}(\mathrm{S})
$$

where $E_{\mathrm{V}}(\mathrm{S})$ is the measured potential difference when the solution of $\mathrm{pH}(\mathrm{S})$ in Cell $\mathrm{V}$ is a primary or secondary standard buffer. The intercept, or "standard potential", $E_{\mathrm{V}}{ }^{\circ}$ and $k^{\prime}$, the practical slope are determined by linear regression of eq. 17 [39-41].

$\mathrm{pH}(\mathrm{X})$ of an unknown solution is then obtained from the potential difference, $E_{\mathrm{V}}(\mathrm{X})$, by

$$
\mathrm{pH}(\mathrm{X})=\left[E_{\mathrm{V}}^{\circ}-E_{\mathrm{V}}(\mathrm{X})\right] / k^{\prime}
$$

Additional quantities obtainable from the regression procedure applied to eq. 17 are the uncertainties $u\left(k^{\prime}\right)$ and $u\left(E_{\mathrm{V}}{ }^{\circ}\right)$ [40]. Multipoint calibration is recommended when minimum uncertainty and maximum consistency are required over a wide range of $\mathrm{pH}(\mathrm{X})$ values. This applies, however, only to that range of $\mathrm{pH}$ values in which the calibration function is truly linear. In nonlinear regions of the calibration function, the two-point method has clear advantages provided that $\mathrm{pH}\left(\mathrm{S}_{1}\right)$ and $\mathrm{pH}\left(\mathrm{S}_{2}\right)$ are selected to be as close to $\mathrm{pH}(\mathrm{X})$ as possible.

Details of the uncertainty computations for the multipoint calibration have been given [40], and an example is given in the Annex. The uncertainties are recommended as a means of checking the performance characteristics of $\mathrm{pH}$ meter-electrode assemblies [40]. By careful selection of electrodes for multipoint calibration, uncertainties of the unknown $\mathrm{pH}(\mathrm{X})$ can be kept as low as $U[\mathrm{pH}(\mathrm{X})]=0.01$.

In modern microprocessor $\mathrm{pH}$ meters, potential differences are often transformed automatically into $\mathrm{pH}$ values. Details of the calculations involved in such transformations, including the uncertainties, are available [41].

\section{GLOSSARY $[2,15,44]$}

\subsection{Primary method of measurement}

A primary method of measurement is a method having the highest metrological qualities, whose operation can be completely described and understood, for which a complete uncertainty statement can be written down in terms of SI units. 
A primary direct method measures the value of an unknown without reference to a standard of the same quantity.

A primary ratio method measures the value of a ratio of an unknown to a standard of the same quantity; its operation must be completely described by a measurement equation.

\subsection{Primary standard}

Standard that is designated or widely acknowledged as having the highest metrological qualities and whose value is accepted without reference to other standards of the same quantity.

\subsection{Secondary standard}

Standard whose value is assigned by comparison with a primary standard of the same quantity.

\subsection{Traceability}

Property of the result of a measurement or the value of a standard whereby it can be related to stated references, usually national or international standards, through an unbroken chain of comparisons all having stated uncertainties. The concept is often expressed by the adjective traceable. The unbroken chain of comparisons is called a traceability chain.

\subsection{Primary pH standards}

Aqueous solutions of selected reference buffer solutions to which $\mathrm{pH}(\mathrm{PS})$ values have been assigned over the temperature range $0-50{ }^{\circ} \mathrm{C}$ from measurements on cells without transference, called Harned cells, by use of the Bates-Guggenheim convention.

\subsection{Bates-Guggenheim convention}

A convention based on a form of the Debye-Hückel equation that approximates the logarithm of the single ion activity coefficient of chloride and uses a fixed value of 1.5 for the product $B a$ in the denominator at all temperatures in the range $0-50{ }^{\circ} \mathrm{C}$ (see eqs. 4,5 ) and ionic strength of the buffer $<0.1 \mathrm{~mol}$ $\mathrm{kg}^{-1}$.

\subsection{Secondary pH standards}

Values that may be assigned to secondary standard $\mathrm{pH}(\mathrm{SS})$ solutions at each temperature:

i. with reference to [pH(PS)] values of a primary standard of the same nominal composition by Cell III,

ii. with reference to [pH(PS)] values of a primary standard of different composition by Cells II, IV or $\mathrm{V}$, or

iii. by use of Cell I.

Note 15: This is an exception to the usual definition, see Section 12.3.

\section{$12.8 \mathrm{pH}$ glass electrode}

Hydrogen-ion responsive electrode usually consisting of a bulb, or other suitable form, of special glass attached to a stem of high-resistance glass complete with internal reference electrode and internal fill- 
ing solution system. Other geometrical forms may be appropriate for special applications, e.g., capillary electrode for measurement of blood $\mathrm{pH}$.

\subsection{Glass electrode error}

Deviation of a glass electrode from the hydrogen-ion response function. An example often encountered is the error due to sodium ions at alkaline $\mathrm{pH}$ values, which by convention is regarded as positive.

\subsection{Hydrogen gas electrode}

A thin foil of platinum electrolytically coated with a finely divided deposit of platinum or (in the case of a reducible substance) palladium metal, which catalyzes the electrode reaction: $\mathrm{H}^{+}+\mathrm{e} \rightarrow 1 / 2 \mathrm{H}_{2}$ in solutions saturated with hydrogen gas. It is customary to correct measured values to standard $1 \mathrm{~atm}$ $(101.325 \mathrm{kPa})$ partial pressure of hydrogen gas.

\subsection{Reference electrode}

External electrode system that comprises an inner element, usually silver-silver chloride, mercury-mercury(I) chloride (calomel), or thallium amalgam-thallium(I) chloride, a chamber containing the appropriate filling solution (see 12.14), and a device for forming a liquid junction (e.g., capillary) ceramic plug, frit, or ground glass sleeve.

\subsection{Liquid junction}

Any junction between two electrolyte solutions of different composition. Across such a junction there arises a potential difference, called the liquid junction potential. In Cells II, IV, and V, the junction is between the $\mathrm{pH}$ standard or unknown solution and the filling solution, or the bridge solution (q.v.), of the reference electrode.

\subsection{Residual liquid junction potential error}

Error arising from breakdown in the assumption that the LJPs cancel in Cell II when solution X is substituted for solution $\mathrm{S}$ in Cell V.

\subsection{Filling solution (of a reference electrode)}

Solution containing the anion to which the reference electrode of Cells IV and V is reversible, e.g., chloride for silver-silver chloride electrode. In the absence of a bridge solution (q.v.), a high concentration of filling solution comprising almost equitransferent cations and anions is employed as a means of maintaining the LJP small and approximately constant on substitution of unknown solution for standard solution(s).

\subsection{Bridge (or salt bridge) solution (of a double junction reference electrode)}

Solution of high concentration of inert salt, preferably comprising cations and anions of equal mobility, optionally interposed between the reference electrode filling and both the unknown and standard solution, when the test solution and filling solution are chemically incompatible. This procedure introduces into the cell a second liquid junction formed, usually, in a similar way to the first. 


\subsection{Calibration}

Set of operations that establish, under specified conditions, the relationship between values of quantities indicated by a measuring instrument, or measuring system, or values represented by a material measure or a reference material, and the corresponding values realized by standards.

\subsection{Uncertainty (of a measurement)}

Parameter, associated with the result of a measurement, which characterizes the dispersion of the values that could reasonably be attributed to the measurand.

\subsection{Standard uncertainty, $u_{x}$}

Uncertainty of the result of a measurement expressed as a standard deviation.

\subsection{Combined standard uncertainty, $u_{c}(y)$}

Standard uncertainty of the result of a measurement when that result is obtained from the values of a number of other quantities, equal to the positive square root of a sum of terms, the terms being the variances, or covariances of these other quantities, weighted according to how the measurement result varies with changes in these quantities.

\subsection{Expanded uncertainty, $U$}

Quantity defining an interval about the result of a measurement that may be expected to encompass a large fraction of the distribution of values that could reasonably be attributed to the measurand.

Note 16: The fraction may be viewed as the coverage probability or level of confidence of the interval.

Note 17: To associate a specific level of confidence with the interval defined by the expanded uncertainty requires explicit or implicit assumptions regarding the probability distribution characterized by the measurement result and its combined standard uncertainty. The level of confidence that may be attributed to this interval can be known only to the extent to which such assumptions may be justified.

Note 18: Expanded uncertainty is sometimes termed overall uncertainty.

\subsection{Coverage factor}

Numerical factor used as a multiplier of the combined standard uncertainty in order to obtain an expanded uncertainty

Note 19: A coverage factor is typically in the range 2 to 3 . The value 2 is used throughout in the Annex.

\section{ANNEX: MEASUREMENT UNCERTAINTY}

Examples are given of uncertainty budgets for $\mathrm{pH}$ measurements at the primary, secondary, and working level. The calculations are done in accordance with published procedures [15,37]. 
When a measurement $(y)$ results from the values of a number of other quantities, $y=f\left(x_{1}, x_{2}, \ldots x_{i}\right)$, the combined standard uncertainty of the measurement is obtained from the square root of the expression

$$
u_{c}^{2}(y)=\sum_{i=1}^{n}\left(\frac{\partial f}{\partial x_{i}}\right)^{2} \cdot u^{2}\left(x_{i}\right),
$$

where $\frac{\partial f}{\partial x_{i}}$ is called the sensitivity coefficient $\left(c_{i}\right)$. This equation holds for uncorrelated quantities. The equation for correlated quantities is more complex.

The uncertainty stated is the expanded uncertainty, $U$, obtained by multiplying the standard uncertainty, $u_{c}(y)$, by an appropriate coverage factor. When the result has a large number of degrees of freedom, the use of a value of 2 leads to approximately $95 \%$ confidence that the true value lies in the range $\pm U$. The value of 2 will be used throughout this Annex.

The following sections give illustrative examples of the uncertainty calculations for Cells I-V.

After the assessment of uncertainties, there should be a reappraisal of experimental design factors and statistical treatment of the data, with due regard for economic factors before the adoption of more elaborate procedures.

\section{A-1 Uncertainty budget for the primary method of measurement using Cell I}

Experimental details have been published [42-45].

\section{A-1.1 Measurement equations}

The primary method for the determination of $\mathrm{pH}(\mathrm{PS})$ values consists of the following steps (Section 4.1):

1. Determination of the standard potential of the $\mathrm{Ag} \mid \mathrm{AgCl}$ electrode from the acid-filled cell (Cell Ia)

$E^{\circ}=E_{\mathrm{a}}+2 k \lg \left(m_{\mathrm{HCl}} / m^{\circ}\right)+2 k \lg \gamma_{\mathrm{HCl}}-(k / 2) \lg \left(p^{\circ} / p_{\mathrm{H}_{2}}\right)$,

where $E_{\mathrm{Ia}}=E_{\mathrm{a}}-(k / 2) \lg \left(p^{\circ} / p_{\mathrm{H}_{2}}\right), k=(R T / F) \ln 10, p_{\mathrm{H}_{2}}$ is the partial pressure of hydrogen in Cell Ia, and $p^{\circ}$ is the standard pressure.

2. Determination of the acidity function, $\mathrm{p}\left(a_{\mathrm{H}} \gamma_{\mathrm{Cl}}\right)$, in the buffer-filled cell (Cell I)

$-\lg \left(a_{\mathrm{H}} \gamma_{\mathrm{Cl}}\right)=\left(E_{\mathrm{b}}-E^{\circ}\right) / k+\lg \left(m_{\mathrm{Cl}} / m^{\circ}\right)-(1 / 2) \lg \left(p^{\circ} / p_{\mathrm{H}_{2}}\right)$,

where $E_{\mathrm{I}}=E_{\mathrm{b}}-(k / 2) \lg \left(p^{\circ} / p_{\mathrm{H}_{2}}\right), p_{\mathrm{H}_{2}}$ is the partial pressure of hydrogen in Cell I, and $p^{\circ}$ the standard pressure.

3. Extrapolation of the acidity function to zero chloride concentration

$-\lg \left(a_{\mathrm{H}} \gamma_{\mathrm{Cl}}\right)=-\lg \left(a_{\mathrm{H}} \gamma_{\mathrm{Cl}}\right)^{\circ}+S m_{\mathrm{Cl}}$

4. $\mathrm{pH}$ Determination

$\mathrm{pH}(\mathrm{PS})=-\lg \left(a_{\mathrm{H}} \gamma_{\mathrm{Cl}}\right)^{\circ}+\lg \gamma_{\mathrm{Cl}}^{\circ}$

where $\lg \gamma^{\circ}$ Cl is calculated from the Bates-Guggenheim convention (see eq. 6). Values of the Debye-Hückel limiting law slope for 0 to $50{ }^{\circ} \mathrm{C}$ are given in Table A-6 [46].

\section{A-1.2 Uncertainty budget}

Example: $\mathrm{PS}=0.025 \mathrm{~mol} \mathrm{~kg}^{-1}$ disodium hydrogen phosphate $+0.025 \mathrm{~mol} \mathrm{~kg}^{-1}$ potassium dihydrogen phosphate. 
Table A-1a Calculation of standard uncertainty of the standard potential of the silver-silver chloride electrode $\left(E^{\circ}\right)$ from measurements in $m_{\mathrm{HCl}}=0.01 \mathrm{~mol} \mathrm{~kg}^{-1}$.

\begin{tabular}{lcccc}
\hline Quantity & $\begin{array}{c}\text { Estimate } \\
x_{i}\end{array}$ & $\begin{array}{c}\text { Standard } \\
\text { uncertainty } \\
u\left(x_{i}\right)\end{array}$ & $\begin{array}{c}\text { Sensitivity } \\
\text { coefficient } \\
\left|c_{i}\right|\end{array}$ & $\begin{array}{c}\text { Uncertainty } \\
\text { contribution } \\
u_{i}(y)\end{array}$ \\
\hline$E / \mathrm{V}$ & 0.464 & $2 \times 10^{-5}$ & 1 & $2 \times 10^{-5}$ \\
$T / \mathrm{K}$ & 298.15 & $8 \times 10^{-3}$ & $8.1 \times 10^{-4}$ & $6.7 \times 10^{-6}$ \\
$m_{\mathrm{HCl}} / \mathrm{mol} \mathrm{kg}^{-1}$ & 0.01 & $1 \times 10^{-5}$ & 5.14 & $5.1 \times 10^{-5}$ \\
$p_{\mathrm{H}_{2}} / \mathrm{kPa}$ & 101.000 & 0.003 & $1.3 \times 10^{-7}$ & $4.2 \times 10^{-7}$ \\
$\Delta E(\mathrm{Ag} / \mathrm{AgCl}) / \mathrm{V}$ & $3.5 \times 10^{-5}$ & $3.5 \times 10^{-5}$ & 1 & $3.5 \times 10^{-5}$ \\
$\mathrm{Bias}$ potential & & & & \\
$\gamma_{ \pm}$ & 0.9042 & $9.3 \times 10^{-4}$ & 0.0568 & $5.2 \times 10^{-6}$ \\
\hline$u_{\mathrm{c}}\left(E^{\circ}\right)=6.5 \times 10^{-5} \mathrm{~V}$ & & & &
\end{tabular}

Note 20: The uncertainty of method used for the determination of hydrochloric acid concentration is critical. The uncertainty quoted here is for potentiometric silver chloride titration. The uncertainty for coulometry is about 10 times lower.

Table A-1b Calculation of the standard uncertainty of the acidity function $\lg \left(a_{\mathrm{H}} \gamma_{\mathrm{Cl}}\right)$ for $m_{\mathrm{Cl}}=0.005 \mathrm{~mol} \mathrm{~kg}^{-1}$.

\begin{tabular}{lcccc}
\hline Quantity & $\begin{array}{c}\text { Estimate } \\
x_{i}\end{array}$ & $\begin{array}{c}\text { Standard } \\
\text { uncertainty } \\
u\left(x_{i}\right)\end{array}$ & $\begin{array}{c}\text { Sensitivity } \\
\text { coefficient } \\
\left|c_{i}\right|\end{array}$ & $\begin{array}{c}\text { Uncertainty } \\
\text { contribution } \\
u_{i}(y)\end{array}$ \\
\hline$E / \mathrm{V}$ & 0.770 & $2 \times 10^{-5}$ & 16.9 & $3.4 \times 10^{-4}$ \\
$E^{\circ} / \mathrm{V}$ & 0.222 & $6.5 \times 10^{-5}$ & 16.9 & $1.1 \times 10^{-3}$ \\
$T / \mathrm{K}$ & 298.15 & $8 \times 10^{-3}$ & 0.031 & $2.5 \times 10^{-4}$ \\
$m_{\mathrm{Cl}} / \mathrm{mol} \mathrm{kg}^{-1}$ & 0.005 & $2.2 \times 10^{-6}$ & 86.86 & $1.9 \times 10^{-4}$ \\
$p_{\mathrm{H}_{2}} / \mathrm{kPa}$ & 101.000 & 0.003 & $2.2 \times 10^{-6}$ & $7 \times 10^{-6}$ \\
$\Delta E(\mathrm{Ag} / \mathrm{AgCl}) / \mathrm{V}$ & $3.5 \times 10^{-5}$ & $3.5 \times 10^{-5}$ & 16.9 & $5.9 \times 10^{-4}$ \\
\hline
\end{tabular}

$u_{\mathrm{c}}\left[\lg \left(a_{\mathrm{H}} \gamma_{\mathrm{Cl}}\right)\right]=0.0013$

Note 21: If, as is usual practice in some NMIs [42-44], acid and buffer cells are measured at the same time, then the pressure measuring instrument uncertainty quoted above $(0.003 \mathrm{kPa})$ cancels, but there remains the possibility of a much smaller bubbler depth variation between cells.

The standard uncertainty due to the extrapolation to zero added chloride concentration (Section 4.4) depends in detail on the number of data points available and the concentration range. Consequently, it is not discussed in detail here. This calculation may increase the expanded uncertainty (of the acidity function at zero concentration) to $U=0.004$.

As discussed in Section 5.2, the uncertainty due to the use of the Bates-Guggenheim convention includes two components:

i. The uncertainty of the convention itself, and this is estimated to be approximately 0.01 . This contribution to the uncertainty is required if the result is to be traceable to SI, but will not be included in the uncertainty of "conventional" $\mathrm{pH}$ values.

ii. The contribution to the uncertainty from the value of the ionic strength should be calculated for each individual case.

The typical uncertainty for Cell I is between $U=0.003$ and $U=0.004$. 


\section{A-2 Uncertainty budget for secondary pH buffer using Cell II}

$\mathrm{Pt}\left|\mathrm{H}_{2}\right| \mathrm{S}_{2}: \mathrm{KCl}\left(\geq 3.5 \mathrm{~mol} \mathrm{dm}^{-3}\right) \mathrm{S}_{1}\left|\mathrm{H}_{2}\right| \mathrm{Pt}$

Cell II

where $\mathrm{S}_{1}$ and $\mathrm{S}_{2}$ are different buffers.

\section{A-2.1 Measurement equations}

1. Determination of $\mathrm{pH}\left(\mathrm{S}_{2}\right)$

$\mathrm{pH}_{\mathrm{II}}\left(\mathrm{S}_{2}\right)-\mathrm{pH}_{\mathrm{II}}\left(\mathrm{S}_{1}\right)=E_{\mathrm{II}} / k-\left(E_{\mathrm{j} 2}-E_{\mathrm{j} 1}\right) / k$

2. Theoretical slope, $k=(R T / F) \ln 10$

\section{A-2.2 Uncertainty budget}

Table A-2 $\mathrm{S}_{1}=$ primary buffer, $\mathrm{pH}(\mathrm{PS})=4.005, u(\mathrm{pH})=0.003 ; \mathrm{S}_{2}=$ secondary buffer, $\mathrm{pH}(\mathrm{SS})=6.86$. Free-diffusion junctions with cylindrical symmetry formed in vertical tubes were used [25].

\begin{tabular}{lcccc}
\hline Quantity & $\begin{array}{c}\text { Estimate } \\
x_{i}\end{array}$ & $\begin{array}{c}\text { Standard } \\
\text { uncertainty } \\
u\left(x_{i}\right)\end{array}$ & $\begin{array}{c}\text { Sensitivity } \\
\text { coefficient } \\
\left|c_{i}\right|\end{array}$ & $\begin{array}{c}\text { Uncertainty } \\
\text { contribution } \\
u_{i}(y)\end{array}$ \\
\hline $\mathrm{pH}\left(\mathrm{S}_{1}\right)$ & 4.005 & 0.003 & 1 & 0.003 \\
$E_{\mathrm{II}} / \mathrm{V}$ & 0.2 & $1 \times 10^{-5}$ & 16.9 & $1.7 \times 10^{-4}$ \\
$\left(E_{\mathrm{j} 2}-E_{\mathrm{j} 1}\right) / \mathrm{V}$ & $3.5 \times 10^{-4}$ & $3.5 \times 10^{-4}$ & 16.9 & $6 \times 10^{-3}$ \\
$T / \mathrm{K}$ & 298.15 & 0.1 & $1.2 \times 10^{-5}$ & $1.2 \times 10^{-6}$ \\
\hline
\end{tabular}

$u_{\mathrm{c}}\left[\mathrm{pH}\left(\mathrm{S}_{2}\right)\right]=0.007$

Note 22: The error in $E_{\mathrm{II}}$ is estimated as the scatter from 3 measurements. The RLJP contribution is estimated from Fig. 2 as 0.006 in pH; it is the principal contribution to the uncertainty.

Therefore, $U\left[\mathrm{pH}\left(\mathrm{S}_{2}\right)\right]=0.014$.

\section{A-3 Uncertainty budget for secondary pH buffer using Cell III}

$\mathrm{Pt}\left|\mathrm{H}_{2}\right|$ Buffer $\mathrm{S}_{2}$ : Buffer $\mathrm{S}_{1}\left|\mathrm{H}_{2}\right| \mathrm{Pt}$

Cell III

A-3.1 Measurement equations

1. $\mathrm{pH}\left(\mathrm{S}_{2}\right)-\mathrm{pH}\left(\mathrm{S}_{1}\right)=\left(E_{\mathrm{III}}+E_{\mathrm{j}}\right) / k$

2. $k=(R T / F) \ln 10$

For experimental details, see refs. [16,33,38]. 
Table A-3 $\mathrm{pH}\left(\mathrm{S}_{2}\right)$ determination. $\mathrm{S}_{1}=$ primary standard (PS) and $\mathrm{S}_{2}=$ secondary standard (SS) are of the same nominal composition. Example: $0.025 \mathrm{~mol} \mathrm{~kg}^{-1}$ disodium hydrogen phosphate $+0.025 \mathrm{~mol} \mathrm{~kg}{ }^{-1}$ potassium dihydrogen phosphate, $\mathrm{PS}_{1}=6.865$, $u(\mathrm{pH})=0.002$.

\begin{tabular}{lcccr}
\hline Quantity & $\begin{array}{c}\text { Estimate } \\
x_{i}\end{array}$ & $\begin{array}{c}\text { Standard } \\
\text { uncertainty } \\
u\left(x_{i}\right)\end{array}$ & $\begin{array}{c}\text { Sensitivity } \\
\text { coefficient } \\
\left|c_{i}\right|\end{array}$ & $\begin{array}{c}\text { Uncertainty } \\
\text { contribution } \\
u_{i}(y)\end{array}$ \\
\hline $\mathrm{pH}\left(\mathrm{PS}_{1}\right)$ & 6.865 & $2 \times 10^{-3}$ & 1 & $2 \times 10^{-3}$ \\
{$\left[E\left(\mathrm{~S}_{2}\right)-E\left(\mathrm{~S}_{1}\right)\right] / \mathrm{V}$} & $1 \times 10^{-4}$ & $1 \times 10^{-6}$ & 16.9 & $16.9 \times 10^{-6}$ \\
{$\left[E_{\mathrm{id}}\left(\mathrm{S}_{2}\right)-E_{\mathrm{id}}\left(\mathrm{S}_{1}\right)\right] / \mathrm{V}$} & $1 \times 10^{-6}$ & $1 \times 10^{-6}$ & 16.9 & $1.7 \times 10^{-5}$ \\
$E_{\mathrm{j}} / \mathrm{V}$ & $1 \times 10^{-5}$ & $1 \times 10^{-5}$ & 16.9 & $16.9 \times 10^{-5}$ \\
$T / \mathrm{K}$ & 298.15 & $2 \times 10^{-3}$ & $5 \times 10^{-6}$ & $1 \times 10^{-8}$ \\
\hline
\end{tabular}

$u_{\mathrm{c}}\left[\mathrm{pH}\left(\mathrm{S}_{2}\right)\right]=0.002$

Therefore, $U\left[\mathrm{pH}\left(\mathrm{S}_{2}\right]\right)=0.004$. The uncertainty is no more than that of the primary standard $\mathrm{PS}_{1}$. Note 23: $\left[E_{\mathrm{id}}\left(\mathrm{S}_{2}\right)-E_{\mathrm{id}}\left(\mathrm{S}_{1}\right)\right]$ is the difference in cell potential when both compartments are filled with solution made up from the same sample of buffer material. The estimate of $E_{\mathrm{j}}$ comes from the observations made of the result of perturbing the $\mathrm{pH}$ of samples by small additions of strong acid or alkali, and supported by Henderson equation considerations, that $E_{\mathrm{j}}$ contributes about $10 \%$ to the total cell potential difference [33].

\section{A-4 Uncertainty budget for secondary pH buffer using Cell IV}

$\mathrm{Ag}|\mathrm{AgCl}| \mathrm{KCl}\left(\geq 3.5 \mathrm{~mol} \mathrm{dm}^{-3}\right) !$ buffer $\mathrm{S}_{1}$ or $\mathrm{S}_{2}\left|\mathrm{H}_{2}\right| \mathrm{Pt}$

Cell IV

\section{A-4.1 Measurement equations}

1. Determination of $\mathrm{pH}\left(\mathrm{S}_{2}\right)$

$\mathrm{pH}_{\mathrm{IV}}\left(\mathrm{S}_{2}\right)-\mathrm{pH}_{\mathrm{IV}}\left(\mathrm{S}_{1}\right)=-\left[E_{\mathrm{IV}}\left(\mathrm{S}_{2}\right)-\mathrm{E}_{\mathrm{IV}}\left(\mathrm{S}_{1}\right)\right] / k-\left(E_{\mathrm{j} 2}-E_{\mathrm{j} 1}\right) / k$

2. Theoretical slope, $k=(R T / F) \ln 10$

\section{A-4.2 Uncertainty budget}

Table A-4 Example from the work of Paabo and Bates [5] supplemented by private communication from Bates to Covington. $\mathrm{S}_{1}=0.05 \mathrm{~mol} \mathrm{~kg}^{-1}$ equimolal phosphate; $\mathrm{S}_{2}=0.05 \mathrm{~mol} \mathrm{~kg}-1$ potassium hydrogen phthalate. $\mathrm{KCl}=3.5 \mathrm{~mol} \mathrm{dm}{ }^{-3} . \mathrm{S}_{1}=$ primary buffer $\mathrm{PS}_{1}, \mathrm{pH}=6.86, u(\mathrm{pH})=0.003, \mathrm{~S}_{2}=$ secondary buffer $\mathrm{SS}_{2}, \mathrm{pH}=4.01$.

\begin{tabular}{lcccc}
\hline Quantity & $\begin{array}{c}\text { Estimate } \\
x_{i}\end{array}$ & $\begin{array}{c}\text { Standard } \\
\text { uncertainty } \\
u\left(x_{i}\right)\end{array}$ & $\begin{array}{c}\text { Sensitivity } \\
\text { coefficient } \\
\left|c_{i}\right|\end{array}$ & $\begin{array}{c}\text { Uncertainty } \\
\text { contribution } \\
u_{i}(y)\end{array}$ \\
\hline $\mathrm{pH}\left(\mathrm{S}_{1}\right)$ & 6.86 & 0.003 & 1 & 0.003 \\
$\Delta E_{\mathrm{IV}} / \mathrm{V}$ & 0.2 & $2.5 \times 10^{-4}$ & 16.9 & $4 \times 10^{-3}$ \\
$\left(E_{\mathrm{j} 2}-E_{\mathrm{j} 1}\right) / \mathrm{V}$ & $3.5 \times 10^{-4}$ & $3.5 \times 10^{-4}$ & 16.9 & $6 \times 10^{-3}$ \\
$T / \mathrm{K}$ & 298.15 & 0.1 & $1.78 \times 10^{-3}$ & $1.78 \times 10^{-4}$ \\
\hline
\end{tabular}

$u_{\mathrm{c}}\left[\mathrm{pH}\left(\mathrm{S}_{2}\right)\right]=0.008$ 
Note 24: The estimate of the error in $\Delta E_{\mathrm{IV}}$ comes from an investigation of several $3.5 \mathrm{~mol} \mathrm{dm}^{-3}$ $\mathrm{KCl}$ calomel electrodes in phosphate solutions. The RLJP contribution for free-diffusion junctions is estimated from Fig. 2 as $0.006 \mathrm{in} \mathrm{pH.}$

Therefore, $U\left[\mathrm{pH}\left(\mathrm{S}_{2}\right)\right]=0.016$.

\section{A-5 Uncertainty budget for unknown $\mathrm{pH}(\mathrm{X})$ buffer determination using Cell V}

$\mathrm{Ag}|\mathrm{AgCl}| \mathrm{KCl}\left(\geq 3.5 \mathrm{~mol} \mathrm{dm}^{-3}\right)$ ! Buffer $\mathrm{pH}(\mathrm{S})$ or $\mathrm{pH}(\mathrm{X}) \mid$ glass electrode

Cell V

\section{A-5.1 Measurement equations: 2-point calibration (bracketing)}

1. Determination of the practical slope $\left(k^{\prime}\right)$

$k^{\prime}=\left[\left(E_{\mathrm{V}}\left(\mathrm{S}_{2}\right)-E_{\mathrm{V}}\left(\mathrm{S}_{1}\right)\right] /\left[\mathrm{pH}\left(\mathrm{S}_{2}\right)-\mathrm{pH}\left(\mathrm{S}_{1}\right)\right]\right.$

2. Measurement of unknown solution (X)

$\mathrm{pH}(\mathrm{X})=\mathrm{pH}\left(\mathrm{S}_{1}\right)-\left[E_{\mathrm{V}}(\mathrm{X})-E_{\mathrm{V}}\left(\mathrm{S}_{1}\right)\right] / k^{\prime}-\left(E_{\mathrm{j} 2}-E_{\mathrm{j} 1}\right) / k^{\prime}$

\section{A-5.2 Uncertainty budget}

Example of two-point calibration (bracketing) with a pH combination electrode [47].

Table A-5a Primary buffers $\mathrm{PS}_{1}, \mathrm{pH}=7.4, u(\mathrm{pH})=0.003 ; \mathrm{PS}_{2}, \mathrm{pH}=4.01, u(\mathrm{pH})=0.003$. Practical slope $\left(k^{\prime}\right)$ determination.

\begin{tabular}{lcccc}
\hline Quantity & $\begin{array}{c}\text { Estimate } \\
x_{i}\end{array}$ & $\begin{array}{c}\text { Standard } \\
\text { uncertainty } \\
u\left(x_{i}\right)\end{array}$ & $\begin{array}{c}\text { Sensitivity } \\
\text { coefficient } \\
\left|c_{i}\right|\end{array}$ & $\begin{array}{c}\text { Uncertainty } \\
\text { contribution } \\
u_{i}(y)\end{array}$ \\
\hline$\Delta E / \mathrm{V}$ & 0.2 & $5 \times 10^{-4}$ & $2.95 \times 10^{-1}$ & $1.5 \times 10^{-4}$ \\
$T / \mathrm{K}$ & 298.15 & 0.1 & $1.98 \times 10^{-4}$ & $1.98 \times 10^{-5}$ \\
$\left(E_{\mathrm{j} 2}-E_{\mathrm{j} 1}\right) / \mathrm{V}$ & $6 \times 10^{-4}$ & $6 \times 10^{-4}$ & $2.95 \times 10^{-1}$ & $1.8 \times 10^{-4}$ \\
$\Delta \mathrm{pH}$ & 3.39 & $4.24 \times 10^{-3}$ & $1.75 \times 10^{-2}$ & $7.40 \times 10^{-5}$ \\
\hline
\end{tabular}

$u_{\mathrm{c}}\left(k^{\prime}\right)=2.3 \times 10^{-4}$

Table A-5b $\mathrm{pH}(\mathrm{X})$ determination.

\begin{tabular}{lcccc}
\hline Quantity & $\begin{array}{c}\text { Estimate } \\
x_{i}\end{array}$ & $\begin{array}{c}\text { Standard } \\
\text { uncertainty } \\
u\left(x_{i}\right)\end{array}$ & $\begin{array}{c}\text { Sensitivity } \\
\text { coefficient } \\
\left|c_{i}\right|\end{array}$ & $\begin{array}{c}\text { Uncertainty } \\
\text { contribution } \\
u_{i}(y)\end{array}$ \\
\hline $\mathrm{pH}\left(\mathrm{S}_{1}\right)$ & 7.4 & 0.003 & 1 & 0.003 \\
$\Delta E / \mathrm{V}$ & 0.03 & $1.40 \times 10^{-5}$ & 16.95 & $2.37 \times 10^{-4}$ \\
$\left(E_{\mathrm{j} 2}-E_{\mathrm{j} 1}\right) / \mathrm{V}$ & $6.00 \times 10^{-4}$ & $6.00 \times 10^{-4}$ & 16.95 & $1.01 \times 10^{-2}$ \\
$k^{\prime} / \mathrm{V}$ & 0.059 & $2.3 \times 10^{-4}$ & 9.01 & $2.1 \times 10^{-3}$ \\
\hline
\end{tabular}

$u_{\mathrm{c}}[\mathrm{pH}(\mathrm{X})]=1.06 \times 10^{-2}$

Note 25: The estimated error in $\Delta E$ comes from replicates. The RLJP is estimated as $0.6 \mathrm{mV}$.

Therefore, $U[\mathrm{pH}(\mathrm{X})]=0.021$. 


\section{A-5.3 Measurement equations for multipoint calibration}

$$
\begin{aligned}
& E_{\mathrm{V}}(\mathrm{S})=E_{\mathrm{V}}{ }^{\circ}-k^{\prime} \mathrm{pH}(\mathrm{S}) \\
& \mathrm{pH}(\mathrm{X})=\left[E_{\mathrm{V}}{ }^{\circ}-E_{\mathrm{V}}(\mathrm{X})\right] / k^{\prime}
\end{aligned}
$$

Uncertainty budget:

Example: Standard buffers $\mathrm{pH}\left(\mathrm{S}_{1}\right)=3.557, \mathrm{pH}\left(\mathrm{S}_{2}\right)=4.008, \mathrm{pH}\left(\mathrm{S}_{3}\right)=6.865, \mathrm{pH}\left(\mathrm{S}_{4}\right)=7.416$, $\mathrm{pH}\left(\mathrm{S}_{5}\right)=9.182 ; \mathrm{pH}(\mathrm{X})$ was a "ready-to-use" buffer solution with a nominal $\mathrm{pH}$ of 7 .

A combination electrode with capillary liquid junction was used. For experimental details, see ref. [41]; and for details of the calculations, see ref. [45].

Table A-5c

\begin{tabular}{lcccc}
\hline Quantity & $\begin{array}{c}\text { Estimate } \\
x_{i}\end{array}$ & $\begin{array}{c}\text { Standard } \\
\text { uncertainty } \\
u\left(x_{i}\right)\end{array}$ & $\begin{array}{c}\text { Sensitivity } \\
\text { coefficient } \\
\left|c_{i}\right|\end{array}$ & $\begin{array}{c}\text { Uncertainty } \\
\text { contribution } \\
u_{i}(y)\end{array}$ \\
\hline$E^{\circ} / \mathrm{V}$ & -0.427 & $5 \times 10^{-4}$ & 16.96 & 0.0085 \\
$T / \mathrm{K}$ & 298.15 & 0.058 & $1.98 \times 10^{-4}$ & $1.15 \times 10^{-5}$ \\
$E(\mathrm{X}) / \mathrm{V}$ & 0.016 & $2 \times 10^{-4}$ & 16.9 & 0.0034 \\
$k^{\prime} / \mathrm{V}$ & 0.059 & $0.076 \times 10^{-3}$ & 67.6 & 0.0051 \\
\hline
\end{tabular}

$u_{\mathrm{c}}[\mathrm{pH}(\mathrm{X})]=0.005$

Note 26: There is no explicit RLJP error assessment as it is assessed statistically by regression analysis.

The uncertainty will be different arising from the RLJPs if an alternative selection of the five standard buffers was used. The uncertainty attained will be dependent on the design and quality of the commercial electrodes selected.

Therefore, $U[\mathrm{pH}(\mathrm{X})]=0.01$.

Table A-6 Values of the relative permittivity of water [46] and the Debye-Hückel limiting law slope for activity coefficients as $\lg \gamma$ in eq. 6. Values are for $100.000 \mathrm{kPa}$, but the difference from $101.325 \mathrm{kPa}(1 \mathrm{~atm})$ is negligible.

\begin{tabular}{rcc}
\hline$t /{ }^{\circ} \mathrm{C}$ & $\begin{array}{c}\text { Relative } \\
\text { permittivity }\end{array}$ & $\begin{array}{c}A / \\
\mathrm{mol}^{-1 / 2} \mathrm{~kg}^{1 / 2}\end{array}$ \\
\hline 0 & 87.90 & 0.4904 \\
5 & 85.90 & 0.4941 \\
10 & 83.96 & 0.4978 \\
15 & 82.06 & 0.5017 \\
20 & 80.20 & 0.5058 \\
25 & 78.38 & 0.5100 \\
30 & 76.60 & 0.5145 \\
35 & 74.86 & 0.5192 \\
40 & 73.17 & 0.5241 \\
45 & 71.50 & 0.5292 \\
50 & 69.88 & 0.5345 \\
\hline
\end{tabular}




\section{SUMMARY OF RECOMMENDATIONS}

- IUPAC recommended definitions, procedures, and terminology are described relating to $\mathrm{pH}$ measurements in dilute aqueous solutions in the temperature range $0-50{ }^{\circ} \mathrm{C}$.

- The recent definition of primary method of measurement permits the definition of primary standards for $\mathrm{pH}$, determined by a primary method (cell without transference, called the Harned cell) and of secondary standards for $\mathrm{pH}$.

- $\quad \mathrm{pH}$ is a conventional quantity and values are based on the Bates-Guggenheim convention. The assigned uncertainty of the Bates-Guggenheim convention is 0.01 in $\mathrm{pH}$. By accepting this value, $\mathrm{pH}$ becomes traceable to the internationally accepted SI system of measurement.

- The required attributes (listed in Section 6.1) for primary standard materials effectively limit the number of primary substances to six, from which seven primary standards are defined in the $\mathrm{pH}$ range $3-10$ (at $25^{\circ} \mathrm{C}$ ). Values of $\mathrm{pH}(\mathrm{PS})$ from $0-50{ }^{\circ} \mathrm{C}$ are given in Table 2.

- Methods that can be used to obtain the difference in $\mathrm{pH}$ between buffer solutions are discussed in Section 8 . These methods include the use of cells with transference that are practically more convenient to use than the Harned cell, but have greater uncertainties associated with the results.

- Incorporation of the uncertainties for the primary method, and for all subsequent measurements, permits the uncertainties for all procedures to be linked to the primary standards by an unbroken chain of comparisons. Despite its conventional basis, the definition of $\mathrm{pH}$, the establishment of $\mathrm{pH}$ standards, and the procedures for $\mathrm{pH}$ determination are self-consistent within the confidence limits determined by the uncertainty budgets.

- Comparison of values from the cell with liquid junction with the assigned $\mathrm{pH}(\mathrm{PS})$ values of the same primary buffers measured with Cell I makes the estimation of values of the RLJPs possible (Section 7), and the consistency of the seven primary standards can be estimated.

- The Annex (Section 13) to this document includes typical uncertainty estimates for the five cells and measurements described, which are summarized in Table 4.

- The hierarchical approach to primary and secondary measurements facilitates the availability of recommended procedures for carrying out laboratory calibrations with traceable buffers grouped to achieve specified target uncertainties of unknowns (Section 11). The three calibration procedures in common use, one-point, two-point (bracketing), and multipoint, are described in terms of target uncertainties.

\section{REFERENCES}

1. BIPM. Com. Cons. Quantité de Matière 4 (1998). See also: M. J. T. Milton and T. J. Quinn. Metrologia 38, 289 (2001).

2. A. K. Covington, R. G. Bates, R. A. Durst. Pure Appl. Chem. 57, 531 (1985).

3. IUPAC. Quantities, Units and Symbols in Physical Chemistry, $2^{\text {nd }}$ ed., Blackwell Scientific, Oxford (1993).

4. S. P. L. Sørensen and K. L. Linderstrøm-Lang. C. R. Trav. Lab. Carlsberg 15, 6 (1924).

5. R. G. Bates. Determination of $p H$, Wiley, New York (1973).

6. S. P. L. Sørensen. C. R. Trav. Lab. Carlsberg 8, 1 (1909).

7. H. S. Harned and B. B. Owen. The Physical Chemistry of Electrolytic Solutions, Chap. 14, Reinhold, New York (1958).

8. R. G. Bates and R. A. Robinson. J. Solution Chem. 9, 455 (1980).

9. A. G. Dickson. J. Chem. Thermodyn. 19, 993 (1987).

10. R. G. Bates and E. A. Guggenheim. Pure Appl. Chem. 1, 163 (1960).

11. J. N. Brønsted. J. Am. Chem. Soc. 42, 761 (1920); 44, 877, 938 (1922); 45, 2898 (1923).

12. A. K. Covington. Unpublished. 
13. K. S. Pitzer. In K. S. Pitzer (Ed.), Activity Coefficients in Electrolyte Solutions, $2^{\text {nd }}$ ed., p. 91, CRC Press, Boca Raton, FL (1991).

14. A. K. Covington and M. I. A. Ferra. J. Solution Chem. 23, 1 (1994).

15. International Vocabulary of Basic and General Terms in Metrology (VIM), $2^{\text {nd }}$ ed., Beuth Verlag, Berlin (1994).

16. R. Naumann, Ch. Alexander-Weber, F. G. K. Baucke. Fresenius' J. Anal. Chem. 349, 603 (1994).

17. R. G. Bates. J. Res. Natl. Bur. Stand., Phys. Chem. 66A (2), 179 (1962).

18. P. Spitzer. Metrologia 33, 95 (1996); 34, 375 (1997).

19. N. E. Good, G. D. Wright, W. Winter, T. N. Connolly, S. Isawa, K. M. M. Singh. Biochem. J. 5, 467 (1966).

20. A. K. Covington and M. J. F. Rebelo. Ion-Sel. Electrode Rev. 5, 93 (1983).

21. H. W. Harper. J. Phys. Chem. 89, 1659 (1985).

22. J. Bagg. Electrochim. Acta 35, 361, 367 (1990); 37, 719 (1992).

23. J. Breer, S. K. Ratkje, G.-F. Olsen. Z. Phys. Chem. 174, 179 (1991).

24 A. K. Covington. Anal. Chim. Acta 127, 1 (1981).

25. A. K. Covington and M. J. F. Rebelo. Anal. Chim. Acta 200, 245 (1987).

26. D. J. Alner, J. J. Greczek, A. G. Smeeth. J. Chem. Soc. A 1205 (1967).

27. F. G. K. Baucke. Electrochim. Acta 24, 95 (1979).

28. A. K. Clark and A. K. Covington. Unpublished.

29. M. J. G. H. M. Lito, M. F. G. F. C. Camoes, M. I. A. Ferra, A. K. Covington. Anal. Chim. Acta 239, 129 (1990).

30. M. F. G. F. C. Camoes, M. J. G. H. M. Lito, M. I. A. Ferra, A. K. Covington. Pure Appl. Chem. 69, 1325 (1997).

31. A. K. Covington and J. Cairns. J. Solution Chem. 9, 517 (1980).

32. H. B. Hetzer, R. A. Robinson, R. G. Bates. Anal. Chem. 40, 634 (1968).

33. F. G. K. Baucke. Electroanal. Chem. 368, 67 (1994).

34. P. R. Mussini, A. Galli, S. Rondinini. J. Appl. Electrochem. 20, 651 (1990); C. Buizza, P. R. Mussini, T. Mussini, S. Rondinini. J. Appl. Electrochem. 26, 337 (1996).

35. R. P. Buck and E. Lindner. Pure Appl. Chem. 66, 2527 (1994).

36. J. Christensen. J. Am. Chem. Soc. 82, 5517 (1960).

37. Guide to the Expression of Uncertainty (GUM), BIPM, IEC, IFCC, ISO, IUPAC, IUPAP, OIML (1993).

38. F. G. K. Baucke. Anal. Chem. 66, 4519 (1994).

39. F. G. K. Baucke, R. Naumann, C. Alexander-Weber. Anal. Chem. 65, 3244 (1993).

40. R. Naumann, F. G. K. Baucke, P. Spitzer. In PTB-Report W-68, P. Spitzer (Ed.), pp. 38-51, Physikalisch-Technische Bundesanstalt, Braunschweig (1997).

41. S. Ebel. In PTB-Report W-68, P. Spitzer (Ed.), pp. 57-73, Physikalisch-Technische Bundesanstalt, Braunschweig (1997).

42. H. B. Kristensen, A. Salomon, G. Kokholm. Anal. Chem. 63, 885 (1991).

43. P. Spitzer, R. Eberhadt, I. Schmidt, U. Sudmeier. Fresenius' J. Anal. Chem. 356, 178 (1996).

44. Y. Ch. Wu, W. F. Koch, R. A. Durst. NBS Special Publication, 260, p. 53, Washington, DC (1988).

45. BSI/ISO 11095 Linear calibration using reference materials (1996).

46. D. A. Archer and P. Wang. J. Phys. Chem. Ref. Data 19, 371 (1990). See also D. J. Bradley and K. S. Pitzer. J. Phys. Chem. 83, 1599 and errata 3799 (1979); D. P. Fernandez, A. R. H. Goodwin, E. W. Lemmon, J. M. H. Levelt Sengers, R. C. Williams. J. Phys. Chem. Ref. Data 26, 1125 (1997).

47. A. K. Covington, R. Kataky, R. A. Lampitt. Unpublished. 